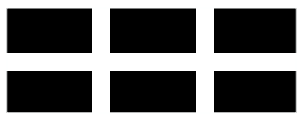

ThE William DAVIDSON INSTITUTE AT THE UNIVERSITY OF MICHIGAN BUSINESS SCHOOL

\title{
Transatlantic Differences in Labour Markets Changes in Wage and Non-Employment Structures in the 1980s and the 1990s
}

\author{
By: Patrick A. Puhani
}

William Davidson Institute Working Paper Number 762

March 2005 


\title{
Transatlantic Differences in Labour Markets Changes in Wage and Non-Employment Structures in the 1980s and the 1990s
}

\author{
Patrick A. Puhani \\ Darmstadt University of Technology; SIAW, University of St. Gallen; \\ IZA, Bonn; WDI, Ann Arbor, MI
}

March 2005

JEL classification: J21, J31, J64

Keywords: wage, earnings, unemployment, non-employment, rigidity, identification

Patrick A. Puhani

Darmstadt University of Technology

Residenzschloss S313/138, Marktplatz 15

64283 Darmstadt

Germany

Phone: $\quad++49-6151-16-3693$

Fax: $\quad++49-6151-16-3897$

E-Mail: puhani@vwl.tu-darmstadt.de 
Abstract: Rising wage inequality in the U.S. and Britain and rising continental European unemployment have led to a popular view in the economics profession that these two phenomena are related to negative relative demand shocks against the unskilled, combined with flexible wages in the Anglo-Saxon countries, but institutional rigidities in continental Europe ('Krugman hypothesis').

This paper tests this hypothesis based on seven large person-level data sets for the 1980s and the 1990s. I use a more sophisticated categorisation of low-skilled workers than previous studies, which highlights the distinction between German workers with and without apprenticeship training. I find evidence for the Krugman hypothesis when Germany is compared to the U.S. However, supply changes differ considerably between countries, with Britain experiencing enormous increases in skill supply explaining the relatively constant British skill premium in the 1990 s.

Acknowledgement: This research was supported by the Volkswagen Foundation. Many thanks also go to IZA, Bonn, for supporting this project and my research visit to IZA. The work on this paper was partly done during my leave during the 2001/2 academic year in the Economics Department at MIT, whose hospitality and support are gratefully acknowledged.

I express my special thanks to Joshua Angrist, Markus Frölich, Michael Lechner, Stephen Machin, and Rudolf Winter-Ebmer for may helpful comments on this paper.

I am furthermore grateful to Daron Acemoglu, David Autor, Thomas Bauer, Stefan Bender, Daniel M. Bernhofen, Martin Biewen, Hoyt Bleakley, Bernhard Boockmann, Mike Brewer, John Brice, Hielke Buddelmeyer, David Card, Donald Cox, Rob Euwals, Christopher Foote, Bernd Fitzenberger, Richard B. Freeman, Michael Gerfin, Peter Gottschalk, Wayne Gray, Anahit Gyurjyan, Caroline M. Hoxby, Lawrence F. Katz, Winfried Koeniger, Astrid Kunze, Ulrich Müller, Gerard Pfann, Michael Pflüger, Steve Pischke, Simone Schmidt, Jeffrey Smith, Reinhold Schnabel, Klaus F. Zimmermann, and seminar participants at Boston College, Clark University, Harvard University, the Institute for the Study of Labor (IZA), MIT, University of Darmstadt, University of Rostock, University of St. Gallen, the Centre for European Economic Research (ZEW), the $10^{\text {th }}$ International Conference on Panel Data in Berlin 2002, and the 2003 meeting of the Ausschuß für Bevölkerungsökonomie (Verein für Socialpolitik) for helpful comments on a previous version of this work. I thank Georgios Tassoukis, IZA, for sending me estimation results from the GLFS and the IABR data. All remaining errors are my own. 


\section{Introduction}

The last quarter of the $20^{\text {th }}$ century has seen a significant increase in wage inequality in the United States and Great Britain. However, this phenomenon has not been observed for Germany to a similar extent ( $c f$. Gottschalk and Smeeding, 1997; Steiner and Wagner, 1998; Fitzenberger, 1999; Katz and Autor, 1999; Acemoglu, 2003 ${ }^{1}$ ). In Germany (and other continental European countries), a significant rise in unemployment has occurred in the 1980s and the 1990s, which contrasts with the fall in British and U.S. joblessness rates, especially during the 1990s. This difference in wage inequality and unemployment developments across the Atlantic led to a view which is sometimes called the 'Krugman hypothesis' (Krugman, 1994). It states that the rise in wage inequality in the Anglo-Saxon countries and the rise in unemployment in continental Europe are 'two sides of the same coin', namely a fall in the relative demand for unskilled workers. $^{2}$

This paper uses several (seven in total) person-level data sets to test whether the low skilled experienced a negative net demand shock in the U.S., Britain, and western Germany in the 1980 s and the 1990s and whether relative wage behaviour for the low skilled was rigid in western Germany but not in the Anglo-Saxon countries. If there is something to the Krugman hypothesis, then Germany - the country with increasing average unemployment - should have experienced a change in the unemployment/non-employment structure such that the relative unemployment likelihood of the unskilled has increased. The U.S. and Britain, however, should have seen a stable (or converging) unemployment but a flexible wage structure. ${ }^{3}$ Unlike previous papers, my results will point to the crucial role of the German apprenticeship system in shielding a large

${ }^{1}$ The large increase in the 90/10 decile ratio reported in Table 1a in Acemoglu (2003) for the early 80s is most likely due to a change in the underlying original data set for Germany, which occurred in the Luxembourg Income Study between 1981 and 1984 (http://www.lisproject.org/techdoc/ge/geindex.htm).

2 The main reason for this fall in relative demand for unskilled workers seems to be skill-biased technological change, rather than trade/globalisation ( $c f$. Katz and Murphy, 1992; Berman, Bound, and Machin, 1998; Machin and Van Reenen, 1998; Pflüger, 2001; Acemoglu, 2002). See Card and DiNardo (2002) for an alternative view for the U.S. and Goux and Maurin (2000) for France.

${ }^{3}$ Figure 1 plots unemployment rates for the U.S., Britain, and Western Germany since the 1960s/1970s. Although there are some issues concerning comparability mentioned in the note to the figure, one may argue that the increase in British and German unemployment in the 1980s was more like a 'catch-up' to standard U.S. levels. It was British, not German unemployment that became exceptionally high during this period. However, in the 1990s both British and U.S. unemployment fell markedly, whereas German unemployment ratched up again. From a macro perspective one might wonder whether this divergence is just a temporary cyclical phenomenon. However, it is the fact that the U.S. and Britain experienced significant increases in wage inequality since the 1970s/1980s, 
section of German workers from the negative demand shocks experienced by low-skilled workers in the United States and Britain. My results are also supportive of recent discussions in Britain to boost vocational education, which are in part influenced by the German apprenticeship system. ${ }^{4}$

Surprisingly, there are not very many papers testing the claims of the Krugman hypothesis and the existing evidence shows mixed results (Nickell and Bell 1995; 1996; Gottschalk and Joyce 1998; Krueger and Pischke, 1997; Card, Kramarz, and Lemieux, 1999). In this paper, I show that the assumption of the absence of supply shocks made in some of the previous literature is not justified. Indeed, there were substantial changes in both the age and education structures of the working age population as well as the labour force in all three countries I investigate. More importantly, these changes clearly differed between the three countries. Therefore, I develop a methodology that does not rely on the assumption of no supply shocks nor does it assume that demand shocks can be proxied. My approach thus differs from and Krueger and Pischke (1997). So do my results: Contrary to these authors (and contrary to Card, Kramarz, and Lemieux, 1999, for France, Canada, and the U.S.), I find support for the Krugman hypothesis. Although being conceptually related to Nickell and Bell $(1995 ; 1996)$ and Gottschalk and Joyce (1998), my methodology is not restricted to only two skill groups ('high' and 'low'), but distinguishes between the age and education dimensions. As to education, I show that by preserving national specificities in the empirical analysis, an important difference arises between low-skilled Germans with and those without apprenticeship training. The previous literature which has attempted to harmonise educational categories across countries was not able to detect this difference ( $c f$. Blau and Kahn, 1996; Kahn, 2000; Acemoglu, 2003). This is not surprising given that data from the OECD's adult literacy survey (IALS) demonstrate that skill contents of 'similar-sounding' schooling types differ a lot between Germany and the U.S. (Freeman and Schettkat, 2000). Pupil test scores reported for the U.S., Britain, Switzerland, and Germany suggest the same (Nickell and Bell, 1996). For judging transatlantic differences in labour market developments, it can therefore be counterproductive to attempt to harmonise diverse educational systems, at least for the purposes of this paper.

The paper is structured as follows. Section 2 describes the data sets used. Studies that analyse a wider spectrum of countries often must compromise on data quality ( $c f$. Blau and Kahn,

whereas Germany did not, which evoked institutional explanations for rising continental European unemployment and made the Krugman hypothesis so widely accepted.

${ }^{4}$ Reform proposals of the Tomlinson report are available on http://www.14-19reform.gov.uk/. 
1996; Gottschalk and Joyce, 1998; Kahn, 2000; Acemoglu, 2003). The Luxembourg Income Study (LIS), for example, contains micro data on many countries, but often only monthly wages for household heads. Furthermore, one has at most 4 waves available for a two-decade period. Hence it is impossible to trace the developments in the 1980s and 1990s in a robust fashion with these data. Similar reservations apply to the International Social Survey Programme (ISSP) data, where in addition the sample size per country is rather small (about 1,000-2,000 observations). Therefore, for each country investigated in this paper, I use at least one data set with 150,000 workers or more in the labour force (with Britain in the 1980s as the only exception). I also check the sensitivity of my results using more than one data source for both Britain and western Germany in the 1990s.

Differences in the changes of the labour supply structures between countries are documented in Section 3 both in the age and the education dimensions. It is in the middle and in the second half of the 1990s when German and Anglo-Saxon unemployment rates diverged. Thus, although the major increase in U.S. and British wage inequality occurred in the 1980s and early 1990s, any test of a hypothesis linking unemployment to the wage structure should also consider what happened during the decade of the 1990s. This is done in Section 4, which presents a 'microeconometric' test of the Krugman hypothesis in the form of statistical inference on changes in the wage and unemployment as well as non-employment structures. Consistent with the Krugman hypothesis, the results support the view that the rise in German unemployment was accompanied by insufficiently flexible wages in face of negative demand shocks against the unskilled. The affected groups are young workers and those with an education below apprenticeship training. Whereas the U.S. has seen an almost continuous increase in between education wage inequality, Britain has not in the 1990s. This difference can however largely be explained by the massive supply changes effected by British educational policy. Section 5 concludes.

\section{Data}

For the United States, I use the Current Population Survey Merged Outgoing Rotation Group (CPS-MORG) files. This is a representative and comfortably large data set frequently used in the related literature. For Britain and western Germany, I use three different data sets. For Britain, the (large) British Labour Force Survey (BLFS) and the British Household Panel Study (BHPS) 
provide the desired information for the 1990s, but for the 1980s, I have to use the General Household Survey (GHS), for reasons explained below. For Germany in the 1990s, I use the German Socio-Economic Panel (GSOEP), the (large) German Labour Force Survey (Mikrozensus, GLFS), and a (large) German administrative data set (IABR). Only the latter survey is available since the beginning of the 1980s, when German unemployment increased sharply.

The optimal data set for my purposes would (1) be representative for the whole population of a country, (2) contain a definition of labour force states in accordance with the International Labour Office (ILO) definition, (3) have accurate information on hourly wage rates, and (4) contain enough observations to guarantee precise statistical measurement.

The U.S. CPS fulfills virtually all these criteria, although wages would be measured more accurately with administrative data. There has been a recoding of the education variable in 1992, which is treated as suggested by Jaeger (1997). Furthermore, I exclude all imputed earnings whenever they are flagged. However, I checked that the inclusion or exclusion of the flagged imputed wages made virtually no difference to my results ( $c f$. Hirsch and Schumacher, 2002).

The British Labour Force Survey (BLFS) is similar to the CPS, but there is no wage information before 1993 in the BLFS and until 1996, only a fifth of the interviewees were asked their labour income. In 1997, this share increased to two fifths. As the BLFS is a quarterly survey, I use all interviews of a calendar year to form an annual sample. As a result, some persons are observed more than once in a calendar year (wherever applicable in the analysis below, standard errors are corrected for clustering). The BHPS has a much smaller sample size than the BLFS, but no clear advantages, except that it can be used as a robustness check. As the provided education variable in the BHPS is coded slightly differently than in the BLFS, I recoded the BHPS variable to make the two data sets better comparable. People on government schemes are identifiable in each wave and are counted as out of the labour force. For the 1980s, I use the General Household Survey (GHS), as the BLFS has no wage information during this period and the BHPS has not existed yet. The definition of O-level and A-level equivalents is different in the GHS from the BLFS, but these differences are not key to the results below. Due to the design of the GHS, I use only full-time workers to measure changes in the structure of wages, but all workers are used to estimate changes in un-/non-employment structures. 
For Germany, the data situation is also complicated (cf. Zimmermann and Wagner, 2002, p. 113). The GSOEP fulfills all criteria except (4), large sample size, and (3) in the sense that it does not contain administrative wage data. Although the ILO definition of the labour force state is not implemented exactly in the GSOEP, non-workers are asked whether they 'certainly want to work again in the future', and whether they could 'start working immediately'. However, before wave 1996, one does not know whether somebody is currently searching for work. The administrative IABR data is strong on criteria (3) and (4) except that this data is top-coded, excludes very low-wage workers, as well as civil servants. Also, hours of work are not reported, only a full-time/part-time indicator. Moreover, this data set does not meet requirements (1) and (2), as it is only sampling workers and people registered with the labour office who receive some form of unemployment benefit. One does not know whether these persons are really searching and are available for work in the short term, as required by the ILO definition of unemployment. Nevertheless, for what it measures, the IABR has the most accurate wage data available for Germany. As this data comes in spell form, I sample people on the $10^{\text {th }}$ of April each year. The German Labour Force Survey (GLFS) meets criteria (1), (2), and (4), but fails on (3), as it only measures after-tax (hourly) income within intervals. This income can come from any sources, not just labour. Also, the top interval is open (implying top coding). Hence, as none of the German data sets comes close to being optimal for my purposes, it is worthwhile to consider all three data sets for Germany to check the robustness of the results for the 1990s. For the complete 1980s, only the IABR data are available. If feasible, I create a gross hourly wage variable (including overtime). This is possible in all countries and data sets except the IABR and the GLFS: in the IABR, I only use full-time workers as hours of work are not available; in the GLFS, I create a net hourly income variable for employed people as a proxy for the hourly wage. Wages of apprentices are excluded in all German data sets for the wage regressions below. In all countries and data sets, wages of self-employed workers are excluded in the analysis of wage structures, but self-employed workers are counted as employed in the analysis of unemployment and nonemployment.

I measure skill in the age and education dimension. Age is discretised into 5 groups, namely 16-25, 26-35, 36-45, 46-55, and 56-65 years. Education is discretised into 4-6 groups depending on the data set and country. In order to acknowledge diversity in the educational systems between countries, I preserve the national education categories instead of allocating 
American labels to non-American degrees. This would be especially difficult in Germany, which operates an apprenticeship system which has no direct equivalent in the U.S. ${ }^{5}$

As some of the previous literature assumes the absence of relative supply shocks, Section 3 provides a descriptive analysis of supply structures before the empirical methodology is developed in Section 4.

\section{Differences in Supply Changes Across Countries}

The graphs in Figure 2 and Figure 3 demonstrate that, first, even within each decade, there were substantial supply side changes within the analysed economies (the results presented in the following are robust to the choice of the labour force instead of the working age population as the proxy for supply). Second, these figures show that the supply side changes differed between the three countries. This is true both in the age and in the education dimensions. The left panels in Figure 2 and Figure 3 display the changes in the age distribution based on the largest and most representative data set for each country (in the 1980s as available). Whereas all countries have experienced changes in the age distribution, the sharp decline in the number of people between 16 and 25 years of age in the British (1990s only) but more so in the German working age population (1980s and 1990s) is striking (the same holds for the labour force). This finding is robust across the various data sets used for these countries. An equally important observation can be made on changes in the educational structure in the right panels in Figure 2 and Figure 3. It is shown in the graphs that, both in the 1980s and the 1990s, all countries have experienced skill upgrading in their working age populations (the same holds for the labour forces). Indeed, all data sets show an increase in the share of workers who have a degree as well as a decrease in the share of workers with the lowest level of education. However, it is very clear just from visual inspection of the graphs that these changes were most dramatic in Britain, caused by educational

\footnotetext{
${ }^{5}$ Numbers of observations for each data set.and sample unemployment and non-employment rates for different skill groups (using sampling weights as provided in the respective data sets) are available upon request. Although west German unemployment in my sample was not massively higher (if at all) in 1997 than in Britain, the data confirm the trends from the OECD data of Figure 1. Especially remarkable is how the vast difference in youth and lowskilled unemployment between the Anglo-Saxon countries and Germany has shrunk during the 1990s. Yet the data also confirm the point made by Nickell and Bell $(1995 ; 1996)$ that the rise in continental European unemployment also affected high-skilled workers. Most of these general trends are also supported by the nonemployment rate figures. An interesting difference, though, is the fact that the non-employment rate of prime-aged workers and persons with a degree did not increase that much in Germany, but the unemployment rate did. However, these raw changes in unemployment rates do not take changes in the composition of the labour force
} 
reforms ( $c f$. Machin, 1996; 1998). The share of workers with no qualification in the working age population (as well as in the labour force) decreased by about 10 percentage points in Britain during the 1990s and by even more than 10 percentage points in the 1980s (slight differences between the GHS and BLFS definitions of O-level equivalents account for small differences in the absolute shares of those below $O$-level equivalent).

In the light of these results, the following section will apply a methodology to test the Krugman hypothesis without making any assumptions on the nature of supply (or demand) shocks.

\section{Differences in the Changes of the Wage, Unemployment, and Non-Employment Structures}

\subsection{Identification of Relative Net Demand Shocks and Relative Wage Rigidities}

The methodology applied in this section identifies relative net demand shocks (i.e. 'increasing' and 'decreasing' labour markets) and wage rigidities. Conceptually, it draws on Nickell and Bell (1996) and Gottschalk and Joyce (1997) in that it uses unemployment/non-employment as a measure of quantity rationing (i.e. the failure of the market to clear) in the presence of wage rigidities. However, unlike these previous studies, I consider several classes of skill in both the age (as a proxy for experience) and education dimensions and control for these as well as other labour market characteristics (gender, region) in a regression framework in both the wage and unemployment models. As a sensitivity check, I also use non-employment (instead of unemployment) as a measure for quantity rationing. The modelling approach does not exclude that there is competition between heterogeneous types of labour.

\section{Theoretical Justification - Net Demand Shocks}

In order to make out increasing and decreasing labour markets, I develop a model that shows how 'net demand shocks' can be identified from the observation of wage and unemployment/nonemployment changes. The framework rests on a neoclassical model of the labour market:

into account, i.e. like the evidence in Nickell and Bell (1995; 1996), they do not provide ceteris paribus comparisons. These ceteris paribus comparisons will be provided in Section 4 of this paper. 


$$
\begin{array}{ll}
S_{t}=S_{t}\left(W_{t}, U_{t}\right) & (L \times 1 \text { vector of labour supplies }) \\
D_{t}=D_{t}\left(W_{t}, U_{t}\right) & (L \times 1 \text { vector of labour demands })
\end{array}
$$

where $D_{t}$ and $S_{t}$ denote vectors of labour demand and supply for $L$ different labour markets, respectively. $W_{t}$ is a vector of wage rates and $Z_{t}$ is a vector of demand and/or supply 'shift factors', like the size of the labour force, technological change or domestic and foreign demand.

Unemployment or non-employment can arise due to a real wage rigidity that causes quantity rationing (i.e. the failure of the market to clear). Unemployment due to rigid wages can be expressed as a function of the vector of wage rates and supply/demand shift factors as

$$
U_{t}=\frac{\left(S_{t}-D_{t}\right)}{S_{t}}=1-\frac{D_{t}\left(W_{t}, Z_{t}\right)}{S_{t}\left(W_{t}, Z_{t}\right)}=U_{t}\left(W_{t}, Z_{t}\right)
$$

( $L \times 1$ vector of latent unemployment rates).

In practice frictional unemployment may be higher for some groups than for others. In order to net out this effect, it is useful to observe changes in unemployment and wages between two points in time $t$ (1980 or 1991 in this paper) and $t+\tau$ (from 1981 to 1990 or from 1992 up to 2001 in this paper). ${ }^{6}$ Using a Taylor expansion one obtains

$$
\Delta_{t}^{t+\tau} U^{l} \approx \underbrace{U_{W}^{l, l} \cdot \Delta_{t}^{t+\tau} W^{l}}_{\text {own wage effect }}+\underbrace{\sum_{\text {cross wage effects }}^{\sum_{j \neq l} U_{W}^{l, j} \cdot \Delta_{t}^{t+\tau} W^{j}}+\underbrace{\sum_{j} U_{Z}^{l, j} \cdot \Delta_{t}^{t+\tau} Z^{j}}_{\text {pure net supply shift effects }}}_{\text {net supply shift effect } \xi^{l}}
$$

where $U_{W}^{l, l}, U_{W}^{l, j}$, and $U_{Z}^{l, j}$ are elements of the Jacobian derivative of $U$ referring to the own wage (the wage in the same labour market), the wages in other labour markets, and the demand/supply shift factors, respectively.

Economic theory allows to impose a light restriction, which is helpful for identification in the econometric analysis: if labour supply and demand schedules are 'upward' and 'downward sloping', respectively, then $U_{W}^{l, l}$ will be positive, because a ceteris paribus increase of the own-

\footnotetext{
${ }^{6}$ Data availability is the reason for a separate consideration of the 1980s and the 1990s. Data availability (for Germany) is also the reason why 1991 and not 1990 is chosen as the base year for the 1990s. Below, I will also discuss sensitivity checks with respect to the base year.
} 
wage will increase unemployment in the corresponding labour market. $U_{W}^{l, l}$ will also be positive in other cases, one of them being 'backward-bending' labour supply behaviour in case the slope of the demand curve is less steep than the one of the supply curve and there is no excess demand for labour. It therefore seems innocuous to impose the restriction that $U_{W}^{l, l}$ is positive.

As to the sign of the cross-wage effects $U_{W}^{l, j}$, economic theory has little to say. This is also true for the sign of the derivative of unemployment with respect to the supply/demand shift variables, $U_{Z}^{l, j}$, as these variables subsume a wide range of unspecified factors. Note that no assumption is made on the size of substitution or any other demand or supply elasticities. These weak assumptions come at the price of not being able to measure demand or supply shocks and wage rigidity quantitatively. However, as can be deduced from equation (2), observation of the signs of the changes in wage and unemployment rates between two points in time identify the sign of the change in the net supply shift effect (i.e. the net supply shock)

$$
\xi^{l}=\underbrace{\sum_{j \neq l} U_{W}^{l, j} \cdot \Delta_{t}^{t+\tau} W^{j}+\sum_{j} U_{Z}^{l, j} \cdot \Delta_{t}^{t+\tau} Z^{j}}_{\text {net supply shift effect }}
$$

in 7 out of 9 cases (distinguished by the sign of wage and unemployment changes, similarly as in Table 1). Note that a negative net demand shock is equivalent to a positive net supply shock, i.e. $\xi^{l}>0$. A negative net demand shock implies a 'decreasing' market, that is, at a given wage, demand is falling faster than supply. 


\section{Relative Net Demand Shocks}

However, the question posed by the Krugman (1994) hypothesis is not whether low-skilled workers experienced a negative net demand shock, but whether they faced a relative negative net demand shock. A relative negative net demand shock for a labour market $l$ means that the net demand shock experienced by this market is more negative than the one affecting the reference market $r$ (the latter refers to an 'average' market and is defined to be the 1980 or 1991 sample mean of the labour force or of the working age population in this paper). Identification of relative net demand (or supply) shocks is based on observing relative wage and unemployment changes: $\left[\Delta_{t}^{t+\tau} W^{l}-\Delta_{t}^{t+\tau} W^{r}\right]$ and $\left[\Delta_{t}^{t+\tau} U^{l}-\Delta_{t}^{t+\tau} U^{r}\right]$.

The identification of relative net demand shocks also requires an additional assumption, namely $U_{W}^{l, l} \approx U_{W}^{r, r}$. Using a Taylor approximation as for the derivation of (2) one can write:

$$
\begin{aligned}
& {\left[\Delta_{t}^{t+\tau} U^{l}-\Delta_{t}^{t+\tau} U^{r}\right] \approx} \\
& U_{W}^{l, l} \cdot \Delta_{t}^{t+\tau} W^{l}-U_{W}^{r, r} \cdot \Delta_{t}^{t+\tau} W^{r}+\sum_{j \neq l} U_{W}^{l, j} \cdot \Delta_{t}^{t+\tau} W^{j}-\sum_{j \neq r} U_{W}^{r, j} \cdot \Delta_{t}^{t+\tau} W^{j}+ \\
& \sum_{j} U_{Z}^{l, j} \cdot \Delta_{t}^{t+\tau} Z^{j}-\sum_{j} U_{Z}^{r, j} \cdot \Delta_{t}^{t+\tau} Z^{j}
\end{aligned}
$$

Imposing $U_{W}^{l, l} \approx U_{W}^{r, r}$, which means that the own-wage effects on unemployment are similar in labour market $l$ and reference market $r$, yields:

$$
\left[\Delta_{t}^{t+\tau} U^{l}-\Delta_{t}^{t+\tau} U^{r}\right] \approx U_{W}^{l, l}\left[\Delta_{t}^{t+\tau} W^{l}-\Delta_{t}^{t+\tau} W^{r}\right]+\xi^{l, r}
$$

where

$$
\xi^{l, r}=\sum_{j \neq l} U_{W}^{l, j} \cdot \Delta_{t}^{t+\tau} W^{j}-\sum_{j \neq r} U_{W}^{r, j} \cdot \Delta_{t}^{t+\tau} W^{j}+\sum_{j} U_{Z}^{l, j} \cdot \Delta_{t}^{t+\tau} Z^{j}-\sum_{j} U_{Z}^{r, j} \cdot \Delta_{t}^{t+\tau} Z^{j}
$$

is the relative net supply shock.

Hence, by observing relative wage and unemployment changes, $\Delta_{t}^{t+\tau} W^{l}-\Delta_{t}^{t+\tau} W^{r}$ and $\Delta_{t}^{t+\tau} U^{l}-\Delta_{t}^{t+\tau} U^{r}$, and noting that equation (4) holds, even without knowledge of $U_{W}^{l, l}$, the sign of the relative net supply shock $\xi^{l, r}$ (which is the negative of the relative net demand shock) can be identified. $\xi^{l, r}$ is the basis for the classification into 'increasing' $\left(\xi^{l, r}<0\right)$ or 'decreasing' 
$\left(\xi^{l, r}>0\right)$ markets of labour market characteristics in Table 1 as will be shown in the following subsection.

\section{Empirical Implementation}

In order to take the above concepts to individual data, I define a labour market $l$ by its characteristics $\mathbf{x}_{l}$ (e.g. age, education, gender, region; the subscript $l$ will be dropped hereafter), and denote the reference labour market $r$ by $\overline{\mathbf{x}}$ (the 1980 or 1991 sample mean of the labour force). $W$ and $U$ are defined as expected values of the wage rate $w$ and the unemployment indicator $u=1$ (unemployed $)$, respectively. $1(\cdot)$ is the indicator function which takes on value $l$ if the argument is true and 0 otherwise. Hence I define

$$
\begin{aligned}
& {\left[\Delta_{t}^{t+\tau} W^{l}-\Delta_{t}^{t+\tau} W^{r}\right] \equiv E\left[w_{t+\tau}-w_{t} \mid \mathbf{x}\right]-E\left[w_{t+\tau}-w_{t} \mid \overline{\mathbf{x}}\right]} \\
& {\left[\Delta_{t}^{t+\tau} U^{l}-\Delta_{t}^{t+\tau} U^{r}\right] \equiv E\left[u_{t+\tau}-u_{t} \mid \mathbf{x}\right]-E\left[u_{t+\tau}-u_{t} \mid \overline{\mathbf{x}}\right] .}
\end{aligned}
$$

In order to identify labour market characteristics associated with relative earnings or unemployment changes, I parameterise the distributions of $w$ and $u$ in the following way:

$$
\begin{aligned}
& E\left[\ln \mathrm{w}_{\mathrm{t}} \mid \mathbf{x}\right]=\mathbf{x} \boldsymbol{\beta}_{\mathrm{t}} \\
& \mathrm{E}\left[\mathrm{u}_{\mathrm{t}} \mid \mathbf{x}\right]=\Phi\left(\mathbf{x} \boldsymbol{\gamma}_{\mathrm{t}}\right)
\end{aligned}
$$

where $\Phi(\cdot)$ denotes the cumulative distribution function of the standard normal distribution. A transformed version of the (dummy variable) coefficients of these non-linear parametric regression models forms the basis for the classification of each labour market characteristic $x_{k}$ (e.g. young age or low level of education) to its contribution to relative wage and unemployment changes. This contribution is measured by the changes in the transformed (denoted by an asterisk) coefficients over time: $\left(\beta_{t+\tau, k}^{*}-\beta_{t, k}^{*}\right)$ and $\left(\gamma_{t+\tau, k}^{*}-\gamma_{t, k}^{*}\right)$, respectively. The transformed coefficients (as well as their standard errors) are calculated as in Haisken-De New and Schmidt (1997): $\boldsymbol{\beta}_{t}^{*}=(\mathbf{I}-\mathbf{W}) \boldsymbol{\beta}_{t}, \boldsymbol{\gamma}_{t}^{*}=(\mathbf{I}-\mathbf{W}) \boldsymbol{\gamma}_{t}$, where $\mathbf{I}$ is the identity matrix and $\mathbf{W}$ is a matrix containing weights, which in my case are the base period (1980 or 1991) sample means. This transformation sets the 'base category' for all dummy variables equal to the base period sample mean. It can be shown that due to the non-linearity of the log-linear wage regression and the probit model, this 
transformation is necessary to interpret changes in the coefficients over time as contributions to rising relative wages or unemployment likelihoods. Hence, instead of classifying each conceivable labour market defined by all dummy variable groups, one can just classify each labour market characteristic $x_{k}$ into one of the nine cells defined in Table 1, depending on whether it contributed to a rising, constant, or falling relative wage rate or unemployment likelihood. This is the approach taken in the following subsection.

\subsection{Empirical Results on Relative Net Demand Shocks and Relative Wage Rigidities}

In order to focus the discussion on the test of the Krugman hypothesis, Table 2 to Table 4 present the classification results for the low-skilled groups of the age and education variables as defined in Table 1. Table 2 reports results for the 1980s with 1980 as the base year, after which unemployment rose sharply ( $c f$. Figure 1). Results for the 1990s are displayed in Table 3 to Table 4. ${ }^{7}$ Around 5 different categories in both the age and education dimensions are distinguished in the estimations, rather than only allowing for 2 skill types as in the previous section and the studies by Nickell and Bell (1996) or Gottschalk and Joyce (1997). This is important because the low-skilled group is not as homogeneous in Germany as it is in the AngloSaxon countries, as more than half of the German population has received vocational training (apprenticeship), whereas just 20 percent have obtained only ordinary school education. This latter share is much higher in the Anglo-Saxon countries, at around 50 percent in the U.S. and even higher in Britain in the 1990s (cf. Figure 3). ${ }^{8}$

The classification results are based on two-sided $t$-tests with the null hypothesis that there were no changes in the coefficients of the wage or the unemployment/non-employment equation for a certain low-skill characteristic, e.g. age 16-25 years, between the base year (1980 or 1991) and the reporting year mentioned at the top of each column. Sizes of 5 percent of these $t$-tests correspond to a level of 10 percent (which is the upper bound of the true size, the lower bound

\footnotetext{
${ }^{7}$ The choice of 1992 as the base year in the CPS is due to the definition change of the education categories between 1991 and 1992. In the following, I will also discuss results for 1991 and 1993 as the base year when considering the age dimension of skill. The results are robust with respect to the choice of base year. The year 1993 is chosen as base in the BLFS because there is no information on wages before this year.

${ }^{8}$ Contrary to a myth that seems to exist, German workers with apprenticeship training must clearly be defined as 'low' rather than 'high' skilled (if such a simple distinction is to be made). This is demonstrated by the wage regression results of Figure 4c and Figure 5c for the 1980s and 1990s, respectively, which show that this group receives lower wages than workers with German high-school education.
} 
being 5 percent) of the Bonferroni joint test of the null hypothesis $\left(\hat{\beta}_{t+\tau, k}^{*}-\hat{\beta}_{t, k}^{*}\right)=\left(\hat{\gamma}_{t+\tau, k}^{*}-\hat{\gamma}_{t, k}^{*}\right)=0$. As I do not want the level of the joint test to exceed 10 percent, I only consider 5 percent critical values for the $t$-statistics. This testing procedure allows for correlations in the error terms of the wage and unemployment regressions without imposing functional forms on their joint distribution.

Depending on the test results each skill characteristic is classified into one of the nine fields as exhibited in Table 1 (tables and figures of detailed estimation results are presented in the Internet Appendix; figures of estimated education coefficients in the wage and unemployment regressions are displayed in Figure 4 and Figure 5. Classification results for the control variables gender and region are not presented here, but are available on request. The type of classification is reported as a number which is explained in the note to the tables and also corresponds to the numbers in Table 1. If the Krugman (1994) hypothesis were to hold, one would expect that lowskilled (young age, low education) categories in western Germany be classified as (1): 'strongly rigid', (2): 'weakly rigid in a decreasing market', or, if wages were somewhat but not sufficiently flexible, as (3): 'weakly adjusting in a decreasing market'. In the U.S. and in Britain, one would only expect relative wage adjustments, but no changes in relative quantity rationing (at least not to the disadvantage of the unskilled). Hence, low-skilled characteristics for these countries should be classified as (4): 'strongly adjusting in a decreasing market'. Although there is evidence for the Krugman hypothesis in the data, it turns out that the results are not as 'clean'.

\section{Testing the Krugman Hypothesis with Respect to the Age Dimension of Skill}

The classification results for the young age groups are shown in Table 2 and Table 3 for the 1980s and 1990s, respectively (classifications for the other age groups are not displayed, but available upon request). The low-skilled group here consists of workers between ages 16 and 25 (as they hardly have any work experience). With respect to young workers, there is no support for the Krugman hypothesis in the 1980s: In none of the three countries were wages consistently rigid for young workers ( $c f$. Table 2). This result is robust to choosing either 1981 or 1982 instead of 1980 as the base year for the displayed classifications (available upon request). In Germany, the result is also robust with respect to choosing 1984 as the base year. This check is important, because of a change in the registration of wages between 1983 and 1984 in the German IABR 
data: Since 1984, companies have to include fringe benefits when reporting wages (Steiner and Wagner, 1998).

In the 1990s, there is only weak support for the Krugman hypothesis with respect to young workers ( $c f$. Table 3): The evidence for the U.S. surprisingly suggests a strong relative wage rigidity (classification (1)) ${ }^{9}$. Wages for British young workers seem to have reacted to negative net demand shocks, as the prevailing classifications (3): 'weakly adjusting in a decreasing market' and (4): 'strongly adjusting in a decreasing market' for this group indicate. Especially the larger BLFS data set suggests that the unemployment likelihood of the young fell by less than the one of the other age groups (which is apparent from classification (3) and the fact that British unemployment fell on average). This at least suggests that - in spite of relative wage losses - the British wage structure is somewhat less flexible for younger workers than for other groups. For Germany, on the other hand, classifications (3): 'weakly adjusting in a decreasing market' and (1): 'strongly rigid' dominate, which shows that increasing relative youth unemployment in this country is related to insufficiently flexible wages. If one checks the robustness of these results by using non-employment instead of unemployment as the measure for quantity rationing, more support for the Krugman hypothesis emerges for the 1990s (cf. Table 3): The U.S. evidence suggests no rigidity, the preferred British data set, the BLFS, classifies young workers mostly into the 'flexible' class (4), whereas class (3) dominates in the large German GLFS data set. ${ }^{10}$

\section{Testing the Krugman Hypothesis with Respect to the Education Dimension of Skill}

Having found only some weak support for the Krugman (1994) hypothesis in terms of the wage and unemployment/non-employment structures with respect to young age in the 1990s, the

\footnotetext{
${ }^{9}$ However, the results for the U.S. are somewhat more erratic when 1991 or 1993 are chosen as base year, where the 'flexible' classifications (4) and (6) appear as well. Still, in these cases, the classification (1) also appears during the years 1996/97 to 2000, but not in 2001.

${ }^{10}$ Choosing 1992 or 1993 as the base year in the BHPS data reveals no classification (3) in any year (only 4) for neither the unemployment nor the non-employment measures for quantity rationing. Hence, there is no further indication of relative wage rigidity in Britain from this robustness check. For western Germany, however, the finding of relative wage rigidity in the GSOEP data with unemployment as the measure for quantitiy rationing is robust to the choice of 1992 (but not 1993) as the base period. The same holds for the GLFS data set, where classifications (1) and (2) occurr in both the models with unemployment and non-employment when 1993 is chosen as the base year (note that there is no GLFS survey available for 1992). In the IABR data, there is also some indication for relative wage rigidity if 1992 (but not if 1993) is chosen as the base period. Hence, choosing alternative base periods does not change the main conclusion that western Germany exhibits relative rigidity for young workers' wages. Although GSOEP and IABR data might suggest that the rigidity originated between 1991 and 1993, the GLFS data suggest further increases in rigidity even after 1993.
} 
question arises whether the educational wage and unemployment/non-employment structures behaved in a similar way. I will show that with respect to education, there is more evidence for the claim of the Krugman hypothesis that rigid wages for the low-skilled may cause German unemployment. This is true both in the 1980s and in the 1990s, although the developments are more distinct between Germany and the United States in the 1990s. Moreover, the hypothesis only holds for the lowest education groups. In addition, in Britain, supply effects neutralised relative demand changes in the 1990s, which is not taken into account in the simple statement of the hypothesis.

Table 2 and Table 4 present classification results for the education coefficients in the three countries for the 1980s and 1990s, respectively. I report only the two lowest education groups in each country, which are high school and high school dropouts in the U.S., O-level equivalent and below O-level equivalent in Britain, and apprenticeship and below apprenticeship in western Germany. For the lowest education groups in these countries, there is a clear contrast between the Anglo-Saxon economies on the one hand, and western Germany on the other: The large data sets in Germany predominantly display classifications (1): 'strongly rigid' (GLFS data) and (3): 'weakly adjusting in a decreasing market' (IABR data): results here are similar for the 1980s and the 1990s. ${ }^{11}$ In the U.S., by contrast, only the 'flexible' classifications (4): 'strongly adjusting in a decreasing market' and (9): 'converging' are observed in the 1990s (classification (4) also dominates during the end of the 1980s). In Britain, the least skilled group seems not to have experienced a negative relative net demand shock in the 1990s as it did in the 1980s (in the 1980s there are much fewer 'rigid' classifications (3) for the British than the German low skilled). However, as discussed in Section 3, there was a massive decrease in the relative supply of the least educated group in Britain in the 1990s ( $c f$. Figure 3), which must have netted out a relative 'gross' demand shock against this group. Hence, although the differences between western Germany and the United States are striking and consistent with the Krugman hypothesis, the British evidence points to the potential importance of supply side effects, which clearly differed between countries as shown in Section 3. ${ }^{12}$

\footnotetext{
${ }^{11}$ The point estimates of the small GSOEP data set also suggest rising relative unemployment for the least skilled and falling relative wages, but especially the former are mostly not significant as the classifications in Table 4 show.

${ }^{12}$ In the 1980s, choosing 1981 or 1982 instead of 1980 as the base year leads to similar results: The contrast between the Anglo-Saxon economies and Germany becomes even stronger, as the rigid classification (3) vanishes almost completely in these robustness checks for the United States and Britain, but not for western Germany. The
} 
Considering the second lowest skill groups, there is no consistent picture supporting the Krugman hypothesis: In the U.S., classifications (4): 'strongly adjusting in a decreasing market' and (9): 'converging' alternate for high school graduates in the 1990s and classification (4) predominates in the 1980s. The evidence from the large British BLFS data set, however, suggests insufficiently flexible relative wages in terms of classification (3): 'weakly adjusting in a decreasing market' for the 1990s (nothing much happened in the 1980s). In western Germany, the evidence for the 1990s is not robust, with the GLFS exhibiting relative wage rigidity in the form of classification (2): 'weakly rigid in a decreasing market' but the IABR and GSOEP data suggesting otherwise (where classifications (6): 'strongly adjusting in an increasing market' and (7): 'weakly adjusting in an increasing market' prevail). The 1980s evidence supports the view that workers with apprenticeship training were not affected by relative wage rigidities in western Germany: over the decade as a whole, they experienced a positive instead of a negative net demand shock (classification (7)).

If I use non-employment as the measure for quantity rationing ( $c f$. the lowest panel of Table 2 for the 1980s and the lower panel of Table 4 for the 1990s), the results for the 1990s are very similar to those obtained for unemployment as the measure for quantity rationing, except that in the British BLFS the lowest instead of the second lowest skill group displays relative wage rigidity. For the 1980s, however, the Krugman hypothesis breaks down if non-employment is used as the measure for quantity rationing, because wages for the lowest skill groups are now indicated to be rigid in the sense of classification (3), 'weakly adjusting', in both Britain and the United States (for Germany, the only data set available for the complete 1980s is the IABR, which does not allow to measure non-employment as opposed to unemployment). ${ }^{13}$

German results are also robust to choosing 1984 as base year (this check is warranted by the inclusion of fringe benefits in wage measurement in the IABR since 1984, cf. Steiner and Wagner, 1998).

In the 1990s, the classification results for western Germany are robust to the choice of 1992 or 1993 as the base period in all three data sets and in both the models with unemployment and non-employment as the measure for quantity rationing (there are only minor deviations which do not alter the interpretation of the results). The same holds for the British BHPS data with 1992 or 1993 as the base, as well as the U.S. results if 1993 is chosen as the base period.

${ }^{13}$ As in the case of the lowest education groups, the classification results for the second-lowest education groups are robust to the choice of alternative base years. For the 1980s, there is no change to the main results if 1981 or 1982 instead of 1980 is chosen as base year. The German results are also robust to choosing 1984 as base year (this check is warranted by the inclusion of fringe benefits in wage measurement in the IABR since 1984, $c f$. Steiner and Wagner, 1998).

For the 1990s, the classification results for the second-lowest education groups are robust to the choice of 1992 or 1993 as base period in all three German data sets; and in the British BLFS in both the models with unemployment and non-employment as the measure for quantity rationing. The U.S. results are also robust when 1993 is chosen 


\section{The Importance of Apprenticeship Training in Germany and Supply Changes in Britain}

The differences in the results for the two lowest education categories substantiate the value of considering various dimensions of skill as well as more detailed national education characteristics. Unlike previous studies like Nickell and Bell (1996) and Gottschalk and Joyce (1998), I show that distinguishing between additional than just high- and low-skilled groups reveals more sophisticated results: Indeed, both in the 1980s and the 1990s, evidence for Krugman's hypothesis can only be found for the least skilled education groups, but not for German workers with an apprenticeship certificate. The relative supply of apprenticeship certificate holders has not fallen at all in western Germany in the 1980s and not fallen by much during the 1990s ( $c f$. Figure 2c and Figure 3c). Taken together, this evidence is consistent with a point made by Nickell and Bell (1996) and Freeman and Schettkat (2000), namely that a large part of the 'low-skilled' in Germany may have a higher level of human capital than their peers in the Anglo-Saxon countries due to the training they receive through the German apprenticeship system. Indeed, the evidence presented here raises doubts on whether workers who have gone through Germany's apprenticeship system experienced the same relative negative demand shocks as American high school graduates. Previous studies have lumped several low-skilled groups together and therefore blurred this interesting finding: A German-style apprenticeship education seems to convey skills that are of a rather different quality than the American high school (which provides classroom, but no vocational training). Consequently, the major low-skilled groups in the U.S. and Germany do not seem to have experienced the same relative negative demand shocks. However, what supports the view that negative relative demand shocks against the unskilled have been experienced across the industrialised world is that German workers with an educational level below apprenticeship have been affected by such shocks both in the 1980s and in the 1990s. Although my classification results identify only relative net demand shocks for the least skilled in western Germany, the fact that the supply of this group in terms of the working age population (and of the labour force) fell ( $c f$. Figure 2c and Figure 3c) leads to the conclusion that the negative relative net demand shock has been generated by a negative relative 'gross' supply shock and an even more negative relative 'gross' demand shock.

Apart from relying on the classification results based on statistical inference, a look at the point estimates presented graphically in Figure 4 and Figure 5 helps to illustrate the different

as the base period (note that 1991 is not a useful choice due to the definition change of the education variable between 1991 and 1992; cf. Section 2). 
experiences of the three countries. The U.S. educational wage structure displayed in Figure 4a and Figure 5a shows how educational wage inequality increased fairly smoothly throughout the two decades (there might be short pauses in this trend in the late-1980s and the mid-1990s). By contrast, both the educational unemployment (and non-employment) structures became more equal since the mid-1980s. The most striking support for Krugman's hypothesis is revealed by a comparison of the changes in western Germany's unemployment structure with the one of the U.S. in the 1990s ( $c f$. Figure 5a and Figure 5c). The German unemployment structure has become more unequal, whereas the one in the U.S. has become more equal. This is exactly what the Krugman hypothesis states. The least educated in western Germany have also faced an increase in their non-employment likelihood in this period, which is not the case for the least skilled in the U.S., who have experienced a decrease (results are available upon request). However, albeit insufficiently flexible, the west German wage structure has not been completely rigid according to the administrative IABR data set ( $c f$. Figure $5 \mathrm{c}$ for the $1990 \mathrm{~s}$ and Figure $4 \mathrm{c}$ for the $1980 \mathrm{~s}$ ).

What about Britain? Figure 5b shows that, compared to the U.S. experience, the British educational wage structure was fairly stable during the 1990s, although the developments were similar in both countries in the 1980s ( $c f$. Figure 4a/b). The educational unemployment structure did not become much more unequal in neither the 1980s nor the 1990s (cf. Figure 4b and Figure 5b), which contrasts with the German experience, especially when the least skilled are considered in the 1990s. What is interesting about comparing Britain and Germany in the 1980s is that despite large increases in the aggregate unemployment rate in both countries in the early 1980s with a subsequent decrease in the late 1980s ( $c f$. Figure 1), in Britain, these shocks were not accompanied by large swings in the structure of unemployment as they were in Germany. This is further support for the view that unemployment in Germany is more related to the failure of relative wages between skill groups to clear the markets, so that we observe changes in relative quantity rationing. This illustrates the rigidity of the relative wage structure in Germany. For Britain, the broad picture that a stable wage structure could be sustained in the 1990s, without relative unemployment increases for the least educated as in western Germany, can be explained by the substantial relative supply changes as discussed in Section 3. 


\section{Are There Alternative Explanations?}

\section{Sample Selection}

Although the evidence presented here (especially when western Germany and the U.S. are compared) is broadly consistent with the Krugman hypothesis, especially in the 1990s, one may raise alternative explanations for these regression results. One argument could be based on the issue of sample selection in wage regressions (Heckman, 1979; Leung and Yu, 1996): In the face of relative demand shocks against the unskilled, one expects workers with the least unobserved skills to lose their jobs first. Hence, standard wage regressions as presented here might falsely conclude that the wage structure between observed skill categories has remained stable, whereas in fact the price of skills (taking into account observed and unobserved factors) has fallen. At the same time, one would measure an increase in the relative unemployment and non-employment of the least skilled workers, as they either leave the labour force or prefer to draw unemployment benefits instead of working for a lower wage. However, if this explanation is claimed to be the only factor underlying my results, then one would expect an increase in the relative unemployment or relative non-employment for the low skilled not only in western Germany, but also in the U.S. Yet, this did not happen to low education groups in the U.S. in the 1990s (it did in the 1980s, $c f$. Table 2 and Table 4) Therefore, the 'sample selection interpretation' cannot be the main factor driving the empirical observations of this paper for the 1990s.

\section{Changes in Search Intensity}

Another alternative explanation could be that changes in the search intensities of low-skilled workers drive differences across countries in the changes in the relative unemployment and nonemployment likelihoods. If this were the case, the Krugman hypothesis would not be the correct interpretation of the results presented here. In the 1990s, major reforms of the unemployment benefit and welfare systems in the Unites States and in Britain with their emphasis on mandatory job search assistance and the introduction of work requirements were, with the exception of the British New Deal of 1998, not explicitly targeted at young or less educated workers ( $c f$. Monthly Labor Review, various issues; Blank and Haskins, 2001; and Weil, 2002; for the U.S.; Van Reenen, 2001; for Britain). However, the U.S. profiling system for unemployment insurance introduced since 1993 and significant welfare reform triggered by the Personal Responsibility and Work Opportunity Reconciliation Act of 1996 can be expected to have taken effect mostly on 
these socio-economic groups (Blank, 2002). The same holds in Britain for the introduction of the Job Seekers' Allowance in 1996 and the New Deal of 1998. However, also in Germany, welfare eligibility was made more stringent and work incentives were increased through the Welfare Reform Act of 1996. Moreover, there were no significant changes in the unemployment benefit regime in Germany during the 1990s that could explain the increased relative unemployment of the young and the low skilled. ${ }^{14}$ Furthermore, the time pattern of relative unemployment and nonemployment changes for young people in western Germany either suggests a rather smooth increase in relative unemployment of this group, or an increase which is mainly concentrated in the period 1991-1993 ( $c f$. footnote 10). Hence, even if benefits became harder to collect over time in the U.S. thus potentially explaining the convergence in the U.S. unemployment structure, the smooth changes in the German unemployment structure in the 1990s cannot have been caused by changes in the German unemployment benefit or welfare regime.

In the early 1980s, changes in German regulations made unemployment benefit receipt more stringent, but still relative unemployment of the low-skilled increased. Since 1984, the system became more generous again, especially for older workers (Steffen, 2002). Therefore, the steady upward trend in relative unemployment for the least skilled in Germany is not consistent with the timing of changes in unemployment benefit regulations in the 1980s. Similarly, the timing of major changes in unemployment benefit policy in the United States and Britain in the 1980s does not concur with the development of the relative unemployment structures in Figure 4. The relative unemployment likelihood of the least skilled in Britatin remained rather constant overall and even increased despite the introduction of the Restart program in 1987 (cf. Dolton and O'Neill, 2002). Also in the United States, the development of the unemployment structure is rather smooth, despite the large drop in benefit take-up rates in the early 1980s (cf. Blank and Card, 1991; Vroman, 1998). Nevertheless the tightening of eligibility rules since the mid 1980s by many states may have contributed to the decline in relative unemployment of the least skilled (cf. Monthly Labor Review, various issues).

\footnotetext{
${ }^{14}$ The only potential exception are increases in the minimum age for certain prolonged entitlement periods for unemployment benefits in 1997. These affected workers above 42 years of age. However, these changes, which for any given age group only altered the entitlement period by 2 months (e.g. from 14 to 12 months for 42 year olds), were rather minor. A summary of social policy changes in Germany since the 1970s is provided in German in Steffen (2002).
} 


\section{Business Cycles}

A third critique of the interpretation of the results might argue that the three countries are observed at different stages of their business cycles and that changes in wage and unemployment structures are mere reflections of movements within different stages of the business cycle. This argument also does not stand up to scrutiny: Although there are some movements in the wage and unemployment/non-employment structures, visual inspection of these movements in Figure 4 and Figure 5 provides no support that the movement towards more equality in the unemployment structure of the United States is a mere cyclical phenomenon. Instead, it seems to be a trend-like movement from the early 1980s onwards; two decades being a much longer period than the average cycle ( $c f$. Stock and Watson, 1999). Similarly, no cyclical movements can be detected for Britain. In Germany, the increase in relative unemployment of the least skilled has also been a trend-like process in the 1990s and to some extent even in the 1980s, although in the 1980s the sharp increase in unemployment inequality between educational groups had been concurrent with the decreasing growth rates in the early 80s. Similarly, unemployment inequality decreased during the boom in 1989/1990. Nevertheless, even in the 1980s, the relative unemployment incidence of the least skilled in Germany moved almost monotonically upward and never reached the low level of the early 1980s again. Hence, the continuing deterioration in the relative unemployment position of the least skilled in Germany seems to be a systematic problem of the last two decades. A further argument against the business cycle interpretation of my results is provided by the fact that robustness checks on the classifications (statistical tests) as discussed in the footnotes above give credence to the view that the reported main results are not sensitive to varying the base period between the years 1980 and 1982 as well as 1991 and 1993.

\section{Efficiency Wages}

A fourth argument could be that efficiency wages rather than institutions (as claimed by the Krugman hypothesis) are responsible for wage rigidities. Efficiency wages seem to be a particularly unconvincing explanation for least-skilled unemployment. One reason is that the least skilled may be a cheap group to monitor as they mostly do routine tasks which may be easier to evaluate than more diversified tasks of qualified workers ( $c f$. Milgrom and Roberts, 1992, Chapter 12). As monitoring costs are a major ingredient to the efficiency wage hypothesis (Shapiro and Stiglitz, 1984), this raises doubt about efficiency wages explaing the rise in relative 
unemployment for workers without apprenticeship in western Germany. More importantly, the efficiency wage hypothesis cannot explain why experiences should differ as they do between the investigated countries.

In sum, the microeconometric investigation of changes in wage, unemployment, and nonemployment structures with respect to age and education has found some support for the Krugman hypothesis both in the 1980s and even more so in the 1990s. This is especially true when comparing western Germany with the United States.

\section{Conclusions}

Although it seems a consensus view among economists that rising European unemployment and rising inequality in the Anglo-Saxon countries are 'two sides of the same coin', namely a secular fall in the relative demand for the low skilled ('Krugman hypothesis'), there are only few empirical studies testing this hypothesis with individual data. This paper tests the Krugman hypothesis for the 1980s and the 1990s. It is first shown that the assumption of no relative supply shocks made in some of the previous literature is unjustified. Subsequently, a methodology is applied which is agnostic about the nature of demand and supply shocks in its testing procedure. The approach developed in this paper also allows a more sophisticated distinction between different types of low-skilled workers than the previous literature. This turns out to be important, especially when distinguishing between Germans with and without apprenticeship training.

Comparing the U.S. with western Germany renders support for the view that wage rigidities influenced unemployment (and non-employment) developments in Germany: Tests on changes in the wage, unemployment, and non-employment structures with respect to age and education reveal that the lack of sufficient wage flexibility impinged on young and least educated German workers in terms of higher relative unemployment risk. However, there is tentative evidence that persons with a German apprenticeship certificate were not affected by a negative relative (net) demand shock. This suggests that the German vocational education system provides many workers with skills shielding them from both relative wage and relative employment losses. By contrast, the relative wage position of American high-school graduates deteriorated.

On the other hand, the evidence on Britain demonstrates the importance of relative supply effects that helped to keep the educational wage structure constant in the 1990s. 


\section{References}

Acemoglu, D. (2002): Technical Change, Inequality, and the Labor Market, Journal of Economic Literature 40: 7-72.

Acemoglu, D. (2003): Cross-Country Inequality Trends, Economic Journal 113: F121-F149.

Berman, E., J. Bound and S. Machin (1998): Implications of Skill-Biased Technological Change: International Evidence, Quarterly Journal of Economics 113: 1245-79.

Blank, R.M. (2002): Evaluating Welfare Reform in the United States, Journal of Economic Literature 40: 1105-1166.

Blank, R.M. and D.E. Card (1991): Recent Trends in Insured and Uninsured Unemployment: Is There an Explanation?, Quarterly Journal of Economics 106: 1157-1189.

Blank, R.M. and R. Haskins (eds.) (2001): The New World of Welfare, Washington, D.C.: Brookings Institution Press.

Blau, F.D. and L.M. Kahn (1996): International Differences in Male Wage Inequality: Institutions versus Market Forces, Journal of Political Economy 104: 791-837.

Card, D.E., F. Kramarz, and T. Lemieux (1999): Changes in the Relative Structure of Wages and Employment: A Comparison of the United States, Canada, and France, Canadian Journal of Economics 32: 843-877.

Card, D.E. and J.E. DiNardo (2002): Skill Biased Technological Change and Rising Wage Inequality: Some Problems and Puzzles, Journal of Labor Economics 20: 733-783.

Dolton, P. and D. O'Neill (2002): The Long-Run Effects of Unemployment Monitoring and Work-Search Programs: Experimental Evidence from the United Kingdom, Journal of Labor Economics 20: $381-403$

Fitzenberger, B. (1999): Wages and Employment Across Skill Groups, An Analysis for West Germany, Heidelberg: Physica/Springer.

Freeman, R. and R. Schettkat (2000): Skill Compression, Wage Differentials and Employment: Germany vs. the U.S., NBER Working Paper No. 7610, Cambridge, MA.

Gottschalk, P. and M. Joyce (1998): Cross-National Differences in the Rise in Earnings Inequality, Market and Institutional Factors, Review of Economics and Statistics 80: 489-579.

Gottschalk, P. and T.M. Smeeding (1997): Cross-National Comparisons of Earnings and Income Inequality, Journal of Economic Literature 35: 633-687. 
Goux, D. and E. Maurin (2000): The Decline in Demand for Unskilled Labour: An Empirical Analysis Method and its Application to France, Review of Economics and Statistics 82: 596-607.

Haisken-DeNew, J.P. and C.M. Schmidt (1997): Interindustry and Interregion Differentials: Mechanics and Interpretation, Review of Economics and Statistics 79: 516-521.

Heckman, J. J. (1979): Sample Selection Bias as a Specification Error, Econometrica, 47: 153-161.

Hirsch, B.T. and E.D. Schumacher (2002): Match Bias in Wage Gap Estimates Due to Earnings Imputation, Trinity University, TX, and East Carolina University, NC, mimeo.

Jaeger, D.A. (1997): Reconciling the Old and New Census Bureau Education Questions: Recommendations for Researchers, Journal of Business \& Economic Statistics 15: 300-308.

Kahn, L.M. (2000): Wage Inequality, Collective Bargaining, and Relative Employment from 1985 to 1994: Evidence from Fifteen OECD Countries, Review of Economics and Statistics 82: 564-579.

Katz, L. and K. Murphy (1992): Changes in Relative Wages 1963-1987: Supply and Demand Factors, Quarterly Journal of Economics 107: 35-78.

Katz, L.F. and D.H. Autor (1999): Changes in Wage Structure and Earnings Inequality, in: O.C. Ashenfelter and D. Card (eds.): Handbook of Labor Economics. Handbooks in Economics, Vol. 3A. Amsterdam: Elsevier, 1463-1555.

Krueger, A.B. and J-S. Pischke (1997): Observations and Conjectures on the U.S. Employment Miracle, NBER Working Paper No. 6146, Cambridge MA.

Krugman, P. (1994): Past and Prospective Causes of High Unemployment, Economic Review, Federal Reserve Bank of Kansas City, 23-43.

Leung, S., F., Yu, S. (1996): On the Choice Between Sample Selection and Two-Part Models, Journal of Econometrics 72: 197-229.

Machin, S. (1996): Wage Inequality in the UK, Oxford Review of Economic Policy 12: 47-64.

Machin, S. (1998): Recent Shifts in Wage Inequality and the Wage Returns to Education in Britain, National Institute Economic Review 166(4): 87-96.

Machin, S. and J. Van Reenen (1998): Technology and Changes in Skill Structure: Evidence From Seven OECD Countries, Quarterly Journal of Economics 113: 1215-44.

Milgrom, P. and J. Roberts (1992): Economics, Organization and Management, Upper Saddle River, NJ: Prentice Hall. 
Monthly Labor Review (Various Issues): January Issue, 1992-2002, available electronically at http://www.bls.gov/opub/mlr/archive.htm.

Nickell, S. and B. Bell (1995): The Collapse in Demand for the Unskilled and Unemployment across the OECD, Oxford Review of Economic Policy 11: 40-62.

Nickell, S. and B. Bell (1996): Changes in the Distribution of Wages and Unemployment in OECD Countries, American Economic Review Papers and Proceedings 86: 302-321.

Pflüger, M. (2001): Trade, Capital Mobility, and the German Labor Market, Weltwirtschaftliches ArchivReview of World Economics 137: 473-500.

Shapiro, C. and J.E. Stiglitz (1984): Equilibrium Unemployment as a Worker Discipline Device, American Economic Review 74: 433-444.

Steffen, J. (2002): Sozialpolitische Chronik, Bremen, available on the web site http://www.arbeitnehmerkammer.de/sozialpolitik/seiten/1_politik_chronik_sopo.htm.

Steiner, V. and Wagner, K. (1998): Has Earnings Inequality in Germany Changed in the 1980s?, Zeitschrift für Wirtschafts- und Sozialwissenschaften 118: 29-59.

Stock, J.H. and M.W. Watson (1999): Business Cycle Fluctions in U.S. Macroeconomic Time Series, in: J.B. Taylor and M. Woodford (eds.): Handbook of Macroeconomics, Volume 1A, Amsterdam: Elsevier, 3-64.

Van Reenen, J. (2001): No More Skivvy Schemes? Active Labour Market Policies and the British New Deal for the Young Unemployed in Context, Institute for Fiscal Studies (IFS) Working Paper No. 01/09, London.

Vroman, W. (1998): Labor Market Changes and Unemployment Insurance Benefit Availability, U.S. Deparment of Labor, Washington, DC.

Weil, A. (2002): Ten Things Everyone Should Know about Welfare Reform, Assessing the New Federalism, Policy Brief No. A-52, Washington D.C.: The Urban Institute.

Zimmermann, K.F. and G.G. Wagner (2002): Labor Economics, in: K.F. Zimmermann (ed.): Frontiers in Economics, Berlin/Heidelberg: Springer, 95-126. 
Table 1: Relative Wage and Unemployment/Non-Employment Behaviour and Labour Market Classification

\begin{tabular}{|c|c|c|c|}
\hline & $\begin{array}{c}\text { Contributing to a } \\
\text { relative unemployment } \\
\text { decrease }\end{array}$ & $\begin{array}{l}\text { Contributing to a } \\
\text { constant relative } \\
\text { unemployment }\end{array}$ & $\begin{array}{c}\text { Contributing to a } \\
\text { relative unemployment } \\
\text { increase }\end{array}$ \\
\hline & $\left(\gamma_{t+\tau, k}^{*}-\gamma_{t, k}^{*}\right)<0$ & $\left(\gamma_{t+\tau, k}^{*}-\gamma_{t, k}^{*}\right)=0$ & $\left(\gamma_{t+\tau, k}^{*}-\gamma_{t, k}^{*}\right)>0$ \\
\hline $\begin{array}{c}\text { Contributing to a } \\
\text { relative wage increase } \\
\left(\beta_{t+\tau, k}^{*}-\beta_{t, k}^{*}\right)>0\end{array}$ & $\begin{array}{c}\text { (7): } \xi^{l, r}<0 \\
\text { weakly adjusting in } \\
\text { increasing market relative } \\
\text { to the reference market }\end{array}$ & $\begin{array}{c}\text { (6): } \xi^{l, r}<0 \\
\text { strongly adjusting in } \\
\text { increasing market relative } \\
\text { to the reference market }\end{array}$ & $\begin{array}{c}(1): \xi^{l, r}=? \\
\text { strongly rigid } \\
\text { (wage push) relative to } \\
\text { the reference market }\end{array}$ \\
\hline $\begin{array}{c}\text { Contributing to a } \\
\text { constant relative wage } \\
\left(\beta_{t+\tau, k}^{*}-\beta_{t, k}^{*}\right)=0\end{array}$ & $\begin{array}{c}\text { (8): } \xi^{l, r}<0 \\
\text { weakly rigid in increasing } \\
\text { market relative to the } \\
\text { reference market }\end{array}$ & $\begin{array}{l}\text { (5): } \xi=0 \\
\text { stable in stable market } \\
\text { relative to the reference } \\
\text { market }\end{array}$ & $\begin{array}{c}(2): \xi^{l, r}>0 \\
\text { weakly rigid in decreasing } \\
\text { market relative to the } \\
\text { reference market }\end{array}$ \\
\hline $\begin{array}{c}\text { Contributing to a } \\
\text { relative wage decrease } \\
\left(\beta_{t+\tau, k}^{*}-\beta_{t, k}^{*}\right)<0\end{array}$ & $\begin{array}{c}(9): \xi^{l, r}=? \\
\text { converging } \\
\text { (wage pull) relative to the } \\
\text { reference market }\end{array}$ & $\begin{array}{c}(4): \xi^{l, r}>0 \\
\text { strongly adjusting in } \\
\text { decreasing market } \\
\text { relative to the reference } \\
\text { market }\end{array}$ & $\begin{array}{c}(3): \xi^{l, r}>0 \\
\text { weakly adjusting in } \\
\text { decreasing market } \\
\text { relative to the reference } \\
\text { market }\end{array}$ \\
\hline
\end{tabular}

Note: The terminology 'increasing market' refers to a positive relative net demand shock (which is the same as a negative relative net supply shock $\xi^{l, r}<0$ for labour market $l$ with respect to the reference market $r$ as defined in Section 4). Increasing markets relative to the reference market are identified in cases (6), (7), and (8). Analogously, a 'decreasing market' is equivalent to a negative net demand shock. Decreasing markets relative to the reference market are identified in cases (2), (3), and (4). In cases (1) and (9), the sign of the net demand shock cannot be identified, $\xi^{l, r}=$ ?. In case (5), there is no such shock. See also the theoretical discussion in Section 4. 
Table 2: Classification Summary for the 1980s (Codes 1, 2 and 3 Indicate Rigidity)

\begin{tabular}{|c|c|c|c|c|c|c|c|c|c|c|}
\hline Variable & 1981 & 1982 & 1983 & 1984 & 1985 & 1986 & 1987 & 1988 & 1989 & 1990 \\
\hline \multicolumn{11}{|c|}{ Young Age - with Unemployment as the Measure for Quantity Rationing } \\
\hline \multicolumn{11}{|c|}{ U.S. (CPS; Base 1980) } \\
\hline $16-25$ & 4 & 9 & 9 & 9 & 9 & 9 & 9 & 9 & 9 & 9 \\
\hline \multicolumn{11}{|c|}{ Britain (GHS; Base 1980) } \\
\hline $16-25$ & - & 4 & 2 & 4 & 4 & 4 & 9 & 9 & 4 & 4 \\
\hline \multicolumn{11}{|c|}{ Germany (IABR; Base 1980) } \\
\hline $16-25$ & 4 & - & 3 & 6 & 6 & 9 & 9 & 9 & 9 & 9 \\
\hline
\end{tabular}

Young Age - with Non-employment as the Measure for Quantity Rationing

U.S. (CPS; Base 1980)

\begin{tabular}{llllllllll}
$\begin{array}{l}16-25 \\
\text { Britain (GHS; Base 1980) }\end{array}$ & 3 & 3 & 4 & 4 & 4 & 9 & 9 & 9 & 4 \\
$16-25$ & 2 & 3 & 2 & 3 & 4 & 4 & 4 & 9 & 4 \\
\hline
\end{tabular}

Low Level of Education- with Unemployment as the Measure for Quantity Rationing U.S. (CPS; Base 1980)

High School

High School Dropout

Britain (GHS; Base 1980)

O-level equivalent

Below O-level equivalent

\begin{tabular}{llllllllll}
- & 2 & 3 & 4 & 4 & 4 & 4 & 4 & 4 & 4 \\
4 & 3 & 3 & 3 & 3 & 3 & 4 & 4 & 4 & 4 \\
- & - & - & - & - & 8 & - & - & 8 & 6 \\
2 & - & 4 & 4 & 3 & 3 & 4 & 4 & 3 & 4 \\
- & - & 4 & 4 & 4 & 4 & 7 & 7 & 7 & 7 \\
2 & $\mathbf{2}$ & $\mathbf{3}$ & $\mathbf{3}$ & $\mathbf{3}$ & $\mathbf{3}$ & $\mathbf{3}$ & $\mathbf{3}$ & $\mathbf{3}$ & $\mathbf{3}$ \\
\hline
\end{tabular}

Germany (IABR; Base 1980)

Apprenticeship

Below Apprenticeship

n-employment as the Measure for Quantity Rationing

Low Level of Education
U.S. (CPS; Base 1980)

High School

High School Dropout

Britain (GHS; Base 1980)

O-level equivalent

Below O-level equivalent

\begin{tabular}{llllllllll}
- & 2 & 2 & 4 & 3 & 4 & 4 & 4 & 4 & 4 \\
$\mathbf{3}$ & $\mathbf{3}$ & $\mathbf{3}$ & $\mathbf{3}$ & $\mathbf{3}$ & $\mathbf{3}$ & $\mathbf{3}$ & $\mathbf{3}$ & $\mathbf{3}$ & $\mathbf{3}$ \\
8 & - & - & 8 & - & 8 & 8 & 8 & 7 & 7 \\
$\mathbf{2}$ & $\mathbf{2}$ & $\mathbf{3}$ & $\mathbf{3}$ & $\mathbf{3}$ & $\mathbf{3}$ & $\mathbf{3}$ & $\mathbf{3}$ & $\mathbf{3}$ & $\mathbf{3}$ \\
\hline
\end{tabular}

Note: The classifications are based on regression results controlling for age, education, gender, region, as well as the month of interview in the CPS and the GHS.

The classification codes are as follows ( $c f$. Table 1): (1): strongly rigid (rising relative wage and rising relative unemployment); (2): weakly rigid in a decreasing market (constant relative wage and rising relative unemployment); (3): weakly adjusting in a decreasing market (falling relative wage and rising relative unemployment); (4): strongly adjusting in a decreasing market (falling relative wage and constant relative unemployment); $(-=5)$ : stable in a stable market (constant relative wage and constant relative unemployment); (6): strongly adjusting in an increasing market (rising relative wage and constant relative unemployment); (7): weakly adjusting in an increasing market (rising relative wage and falling relative unemployment); (8): weakly rigid in an increasing market (constant relative wage and falling relative unemployment); (9): converging (falling relative wage and falling relative unemployment).

Sources: Current Population Survey - Merged Outgoing Rotation Group Files (CPS); General Household Survey (GHS); German Administrative Data - Institut für Arbeitsmarkt und Berufsforschung Regionalstichprobe (IABR); own calculations. 
Table 3: Young Age Classification Summary for the 1990s (Codes 1, 2 and 3 Indicate Rigidity)

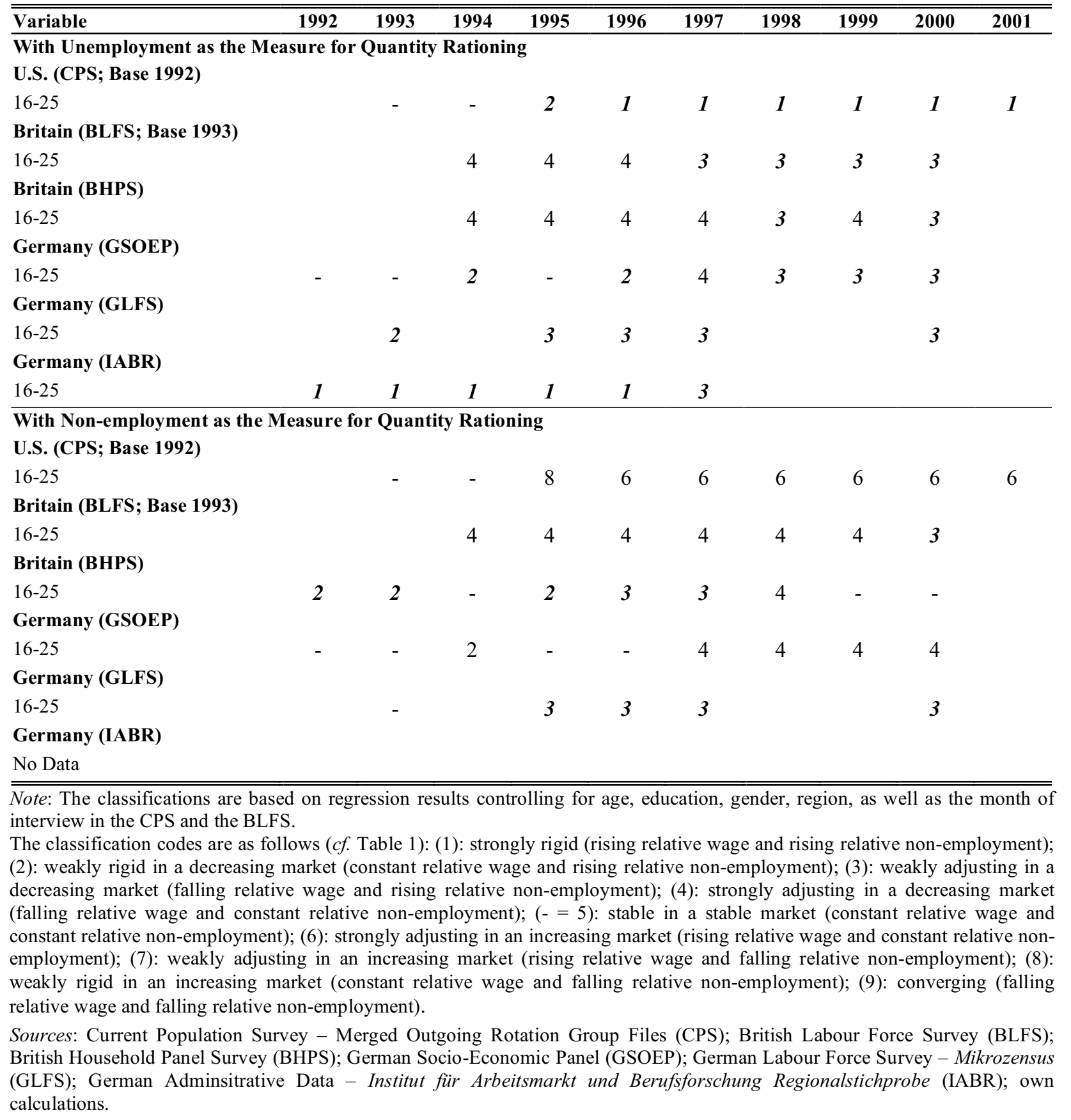


Table 4: Low Level of Education Classification Summary for the 1990s (Codes 1, 2 and 3 Indicate Rigidity)

\begin{tabular}{|c|c|c|c|c|c|c|c|c|c|c|}
\hline Variable & 1992 & 1993 & 1994 & 1995 & 1996 & 1997 & 1998 & 1999 & 2000 & 2001 \\
\hline \multicolumn{11}{|c|}{ With Unemployment as the Measure for Quantity Rationing } \\
\hline \multicolumn{11}{|c|}{ U.S. (CPS; Base 1992) } \\
\hline High School & & - & - & - & 4 & 4 & 4 & 9 & 4 & 9 \\
\hline High School Dropout & & - & 4 & 4 & 4 & 4 & 4 & 9 & 9 & 9 \\
\hline \multicolumn{11}{|l|}{ Britain (BLFS; Base 1993) } \\
\hline O-level equivalent & & & - & - & - & - & 4 & 3 & 3 & \\
\hline Below O-level equivalent & & & - & - & - & - & - & - & - & \\
\hline \multicolumn{11}{|l|}{ Britain (BHPS) } \\
\hline O-level equivalent & - & - & - & - & - & - & - & - & - & \\
\hline Below O-level equivalent & - & - & - & - & - & - & - & - & - & \\
\hline \multicolumn{11}{|l|}{ Germany (GSOEP) } \\
\hline Apprenticeship & 2 & 2 & 2 & 6 & 6 & - & 6 & 6 & 6 & \\
\hline Below Apprenticeship & - & 4 & - & 4 & 4 & - & - & - & 4 & \\
\hline \multicolumn{11}{|l|}{ Germany (GLFS) } \\
\hline Apprenticeship & & 3 & & 2 & 2 & 2 & & & 3 & \\
\hline Below Apprenticeship & & - & & 6 & 1 & 1 & & & 1 & \\
\hline \multicolumn{11}{|l|}{ Germany (IABR) } \\
\hline Apprenticeship & 6 & 6 & 6 & 6 & 7 & 7 & & & & \\
\hline Below Apprenticeship & 4 & 3 & 3 & 3 & 3 & 3 & & & & \\
\hline
\end{tabular}

With Non-employment as the Measure for Quantity Rationing

U.S. (CPS; Base 1992)

High School

High School Dropout

Britain (BLFS; Base 1993)

O-level equivalent

Below O-level equivalent

Britain (BHPS)

O-level equivalent

Below O-level equivalent

Germany (GSOEP)

Apprenticeship

Below Apprenticeship

Germany (GLFS)

Apprenticeship

Below Apprenticeship

Germany (IABR)

No Data

Note: The classifications are based on regression results controlling for age, education, gender, region, as well as the month of interview in the CPS and the BLFS. The classification codes are as follows ( $c f$. Table 1): (1): strongly rigid (rising relative wage and rising relative non-employment); (2): weakly rigid in a decreasing market (constant relative wage and rising relative nonemployment); (3): weakly adjusting in a decreasing market (falling relative wage and rising relative non-employment); (4): strongly adjusting in a decreasing market (falling relative wage and constant relative non-employment); $(-=5)$ : stable in a stable market (constant relative wage and constant relative non-employment); (6): strongly adjusting in an increasing market (rising relative wage and constant relative non-employment); (7): weakly adjusting in an increasing market (rising relative wage and falling relative non-employment); (8): weakly rigid in an increasing market (constant relative wage and falling relative nonemployment); (9): converging (falling relative wage and falling relative non-employment).

Sources: Current Population Survey - Merged Outgoing Rotation Group Files (CPS); British Labour Force Survey (BLFS); British Household Panel Survey (BHPS); German Socio-Economic Panel (GSOEP); German Labour Force Survey - Mikrozensus (GLFS); German Adminsitrative Data - Institut für Arbeitsmarkt und Berufsforschung Regionalstichprobe (IABR); own calculations. 
Figure 1: Unemployment Rates 1960 - 2000

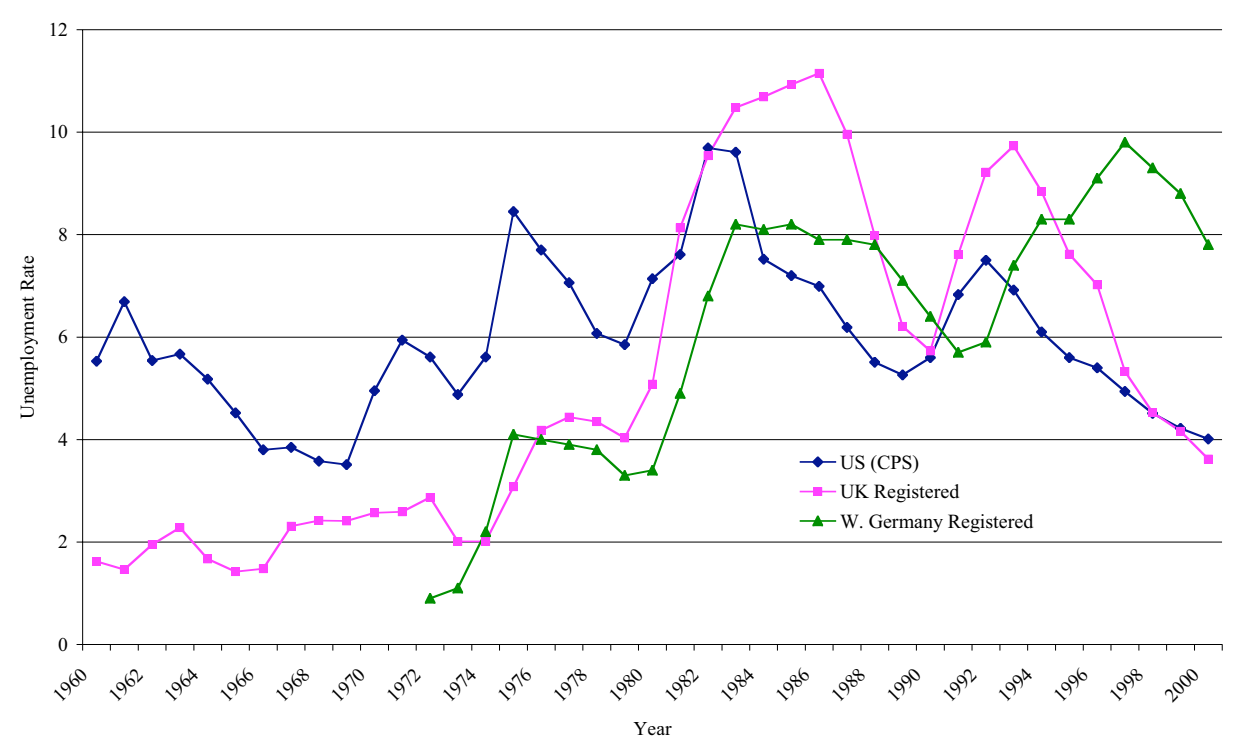

Note: The U.S. unemployment rate is base on the CPS, which uses a definition of unemployment equivalent to the ILO definition. For Western Germany, OECD figures only provide the registered unemployment rate for a longer time period. Comparing the registered with the OECD standardized unemployment rate for united Germany suggests about a 1.5 percent difference between the two, so that the standardised unemployment rate for western Germany would also be lower than depicted in the graph. For the $\mathrm{UK}$, however, the standardised unemployment rate is about 1 percentage point higher than the registered one shown in the graph. It is, however, not available for such a long time period.

Source: OECD. 
Figure 2a: Age and Education Sample Means Working Age Population 1980s - U.S. (CPS)
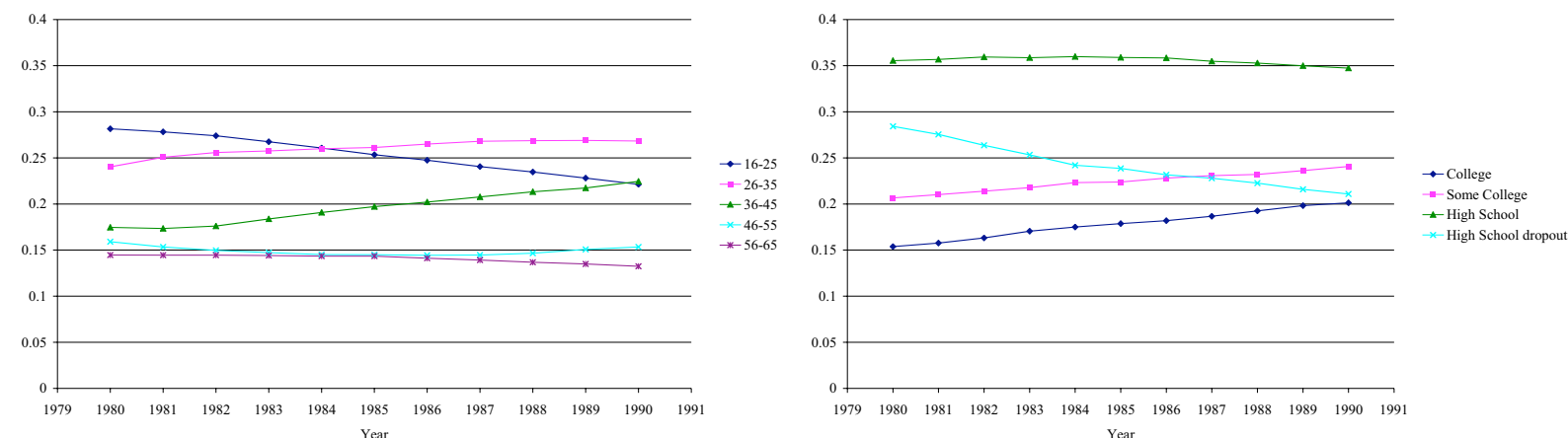

Figure 2b: $\quad$ Age and Education Sample Means Working Age Population 1980s - Britain (GHS)
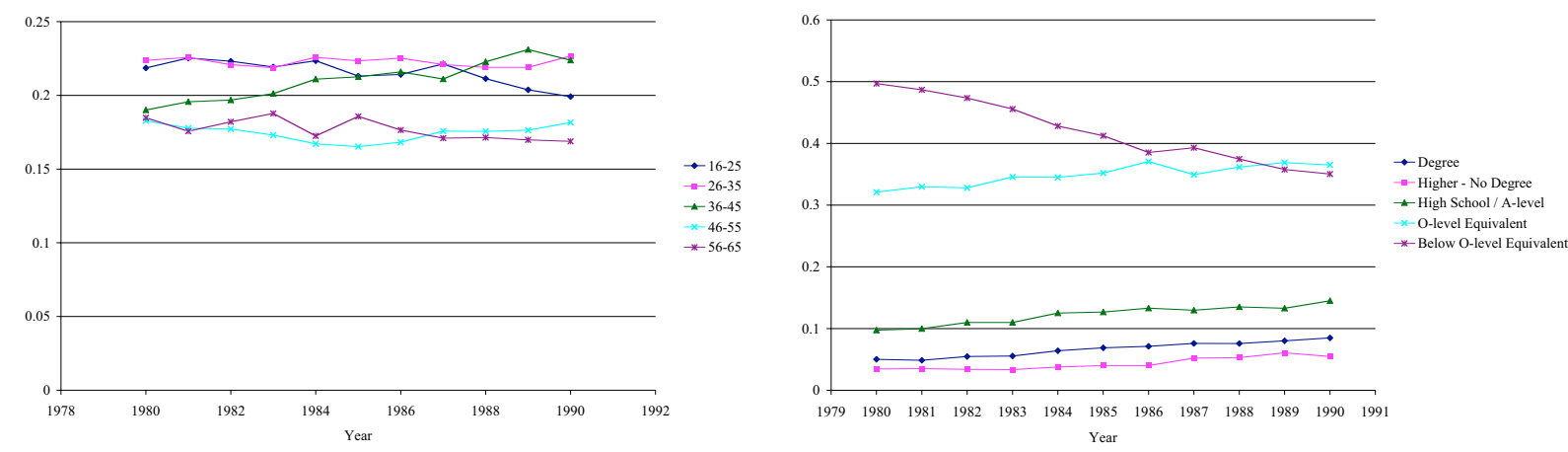

Figure 2c: Age and Education Sample Means Working Age Population 1980s Germany (IABR)
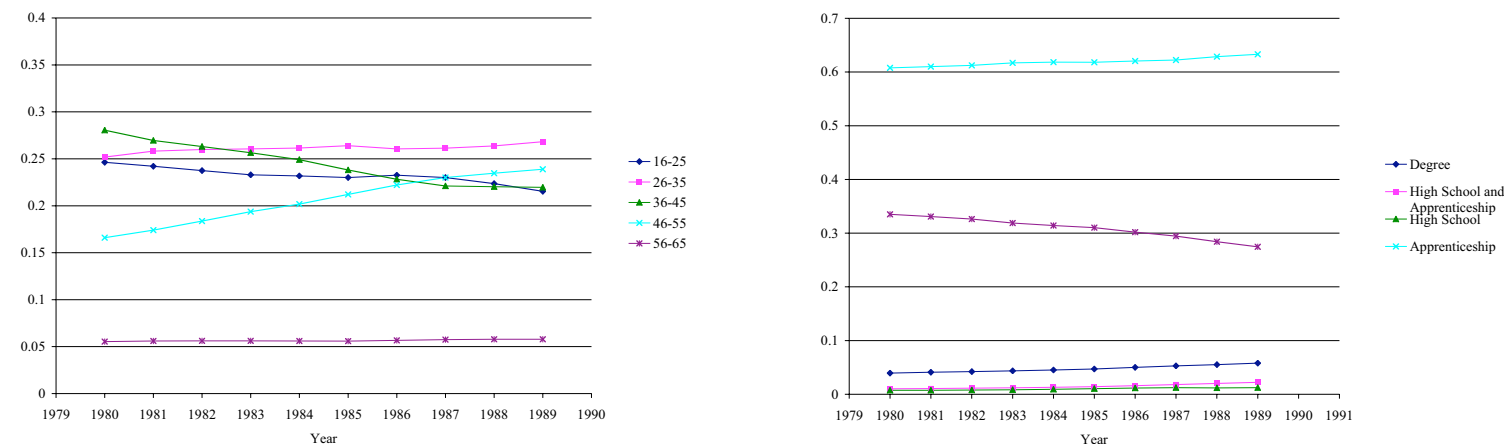

Note: Between 1991 and 1992 the coding of the education variable changed in the CPS, which explains changes in the shares of especially high school graduates and high school dropouts between those years. I therefore use 1992 as the base year for the reported classifications.

Sources: Current Population Survey - Merged Outgoing Rotation Group Files (CPS); General Household Survey (GHS); German Administrative Data - Institut für Arbeitsmarkt und Berufsforschung Regionalstichprobe (IABR). 
Figure 3a: Age and Education Sample Means Working Age Population 1990s - U.S. (CPS)
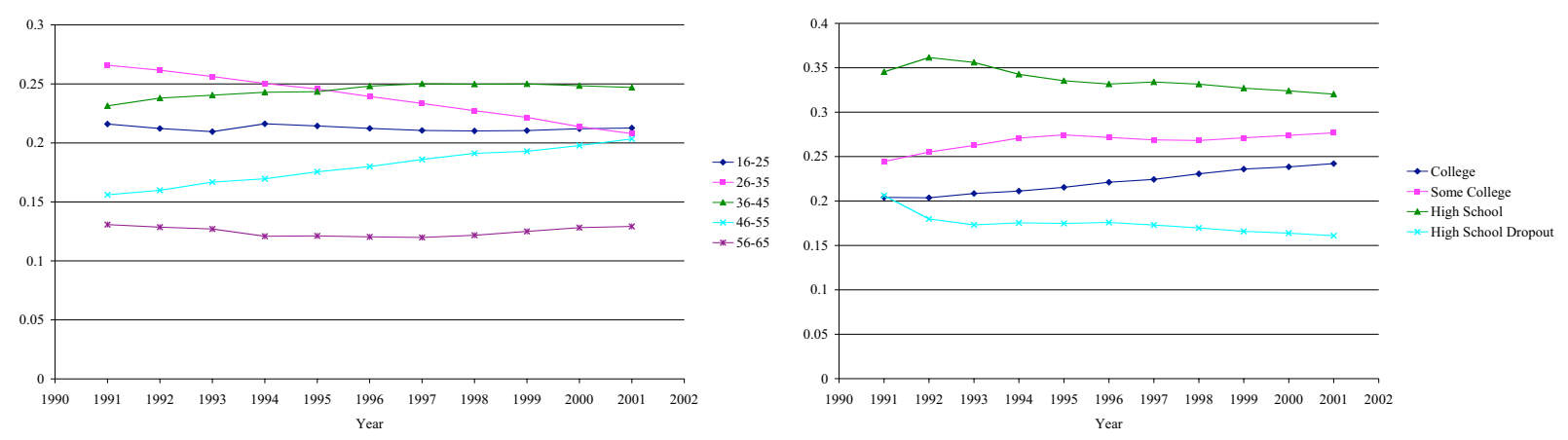

Figure 3b: Age and Education Sample Means Working Age Population 1990s - Britain (BLFS)
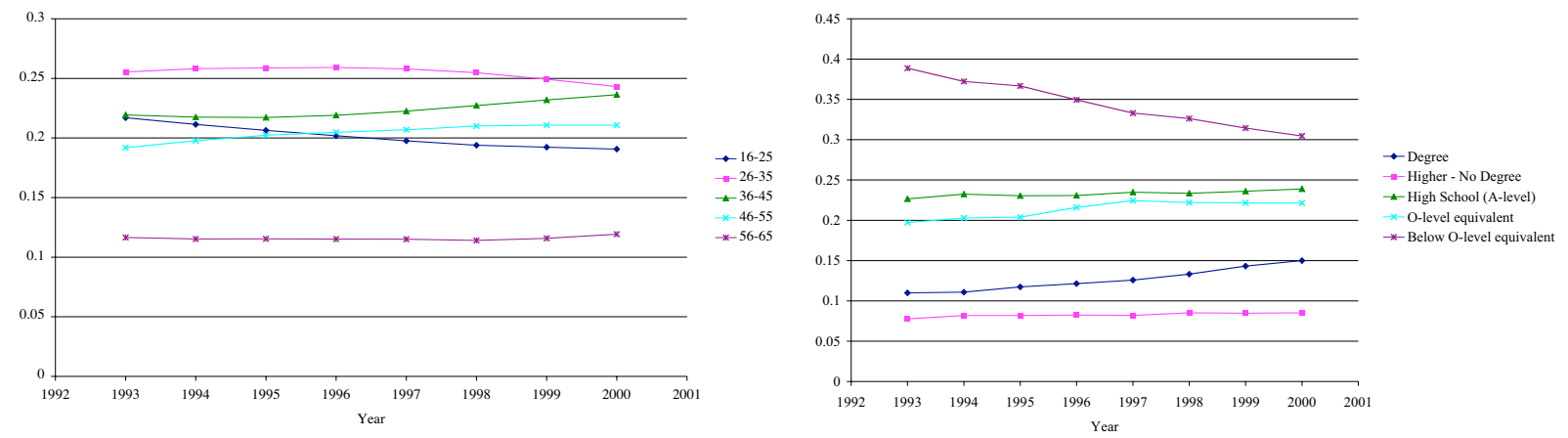

Figure 3c: Age and Education Sample Means Working Age Population 1990s Germany (GLFS)
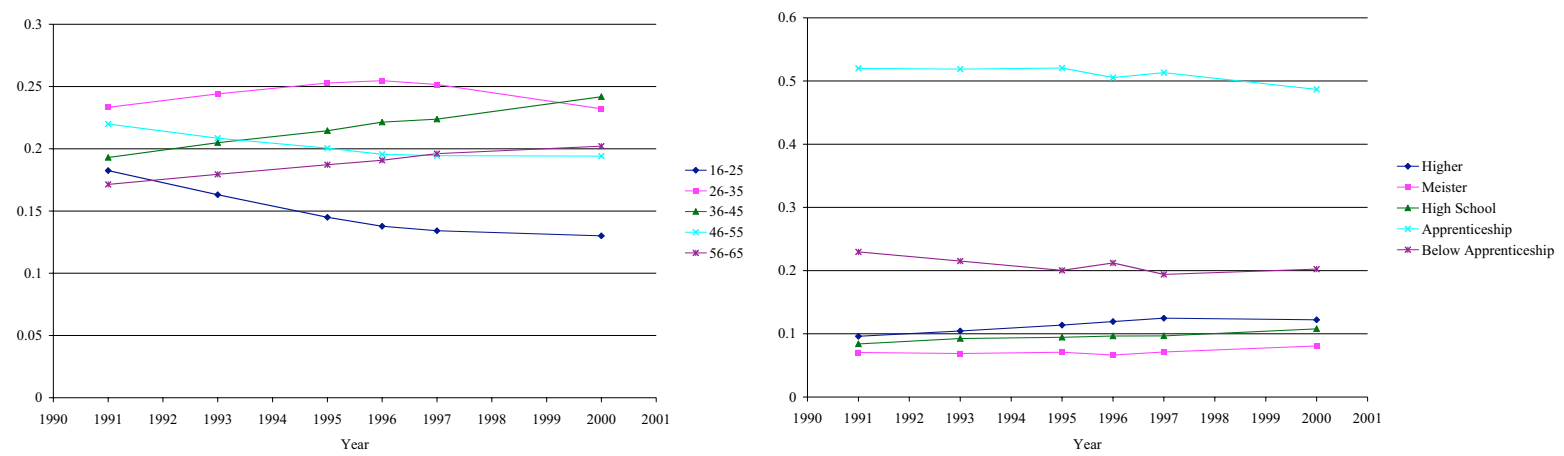

Note: Between 1991 and 1992 the coding of the education variable changed in the CPS, which explains changes in the shares of especially high school graduates and high school dropouts between those years. I therefore use 1992 as the base year for the reported classifications.

Sources: Current Population Survey - Merged Outgoing Rotation Group Files (CPS); British Labour Force Survey (BLFS); German Labour Force Survey - Mikrozensus (GLFS); own calculations. 
Figure 4a: U.S. Wage and Unemployment Regression: Education Coefficients 1980s (CPS)
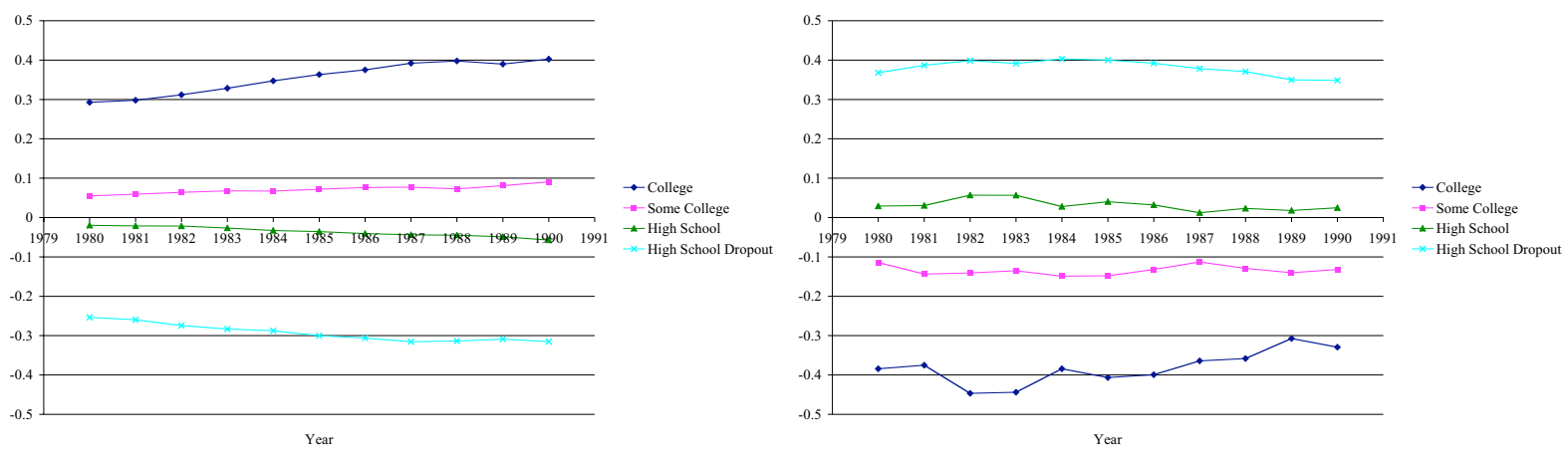

Figure 4b: British Wage and Unemployment Regression: Education Coefficients 1980s (GHS)
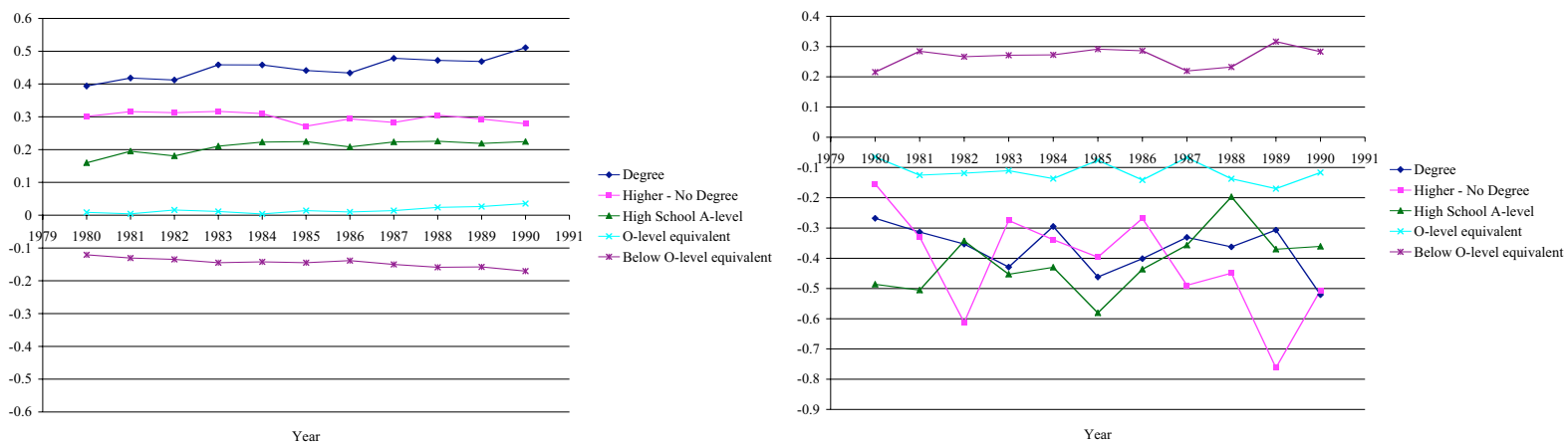

Figure 4c: German Wage and Unemployment Regression: Education Coefficients 1980s - (IABR)
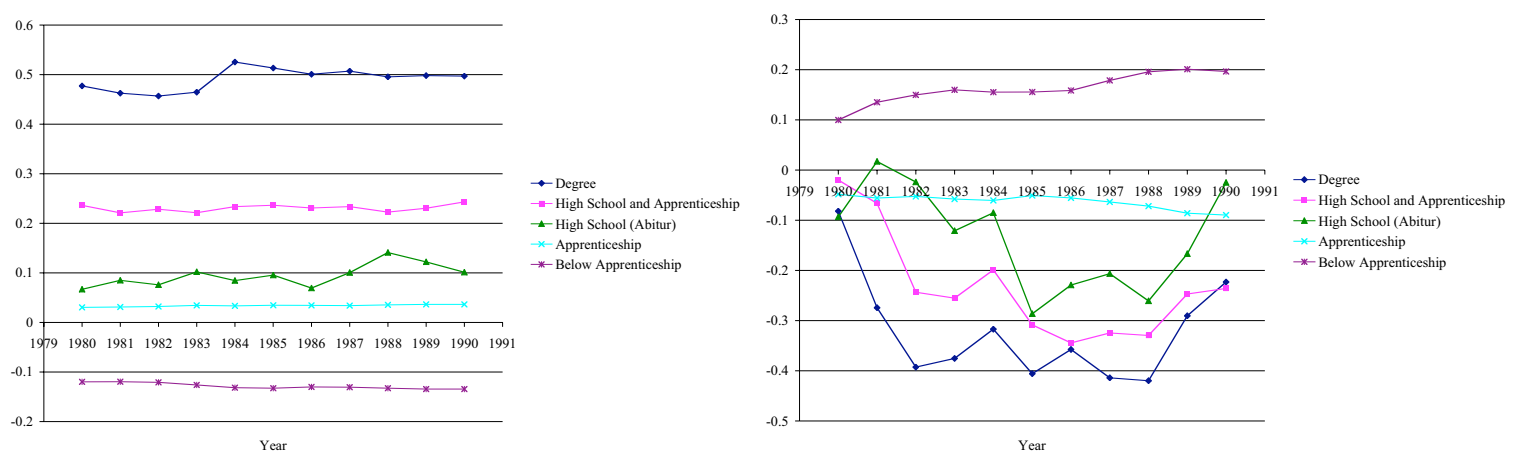

Note: The left and right panels exhibit the transformed wage and unemployment regression coefficients $\beta_{t, k}^{*}$ and $\gamma_{t, k}^{*}$, respectively.

The jump in the relative wages of workers with a degree in the IABR data is explained by a statistical phenomenon: Since 1984, companies have to include fringe benefits when reporting wages for this data set (Steiner and Wagner, 1998). In the paper's text and footnotes, I therefore report sensitivity checks with respect to the choice of the base period for the classifications. It turns out that the change in measurement does not affect the classification results for low-skilled workers in the sense that classification results are essentially the same no matter whether 1980,1981, 1982 or 1984 is chosen as base year.

Sources: Current Population Survey - Merged Outgoing Rotation Group Files (CPS); General Household Survey (GHS); German Administrative Data - Institut für Arbeitsmarkt und Berufsforschung Regionalstichprobe (IABR). 
Figure 5a: U.S. Wage and Unemployment Regression: Education Coefficients 1990s (CPS)
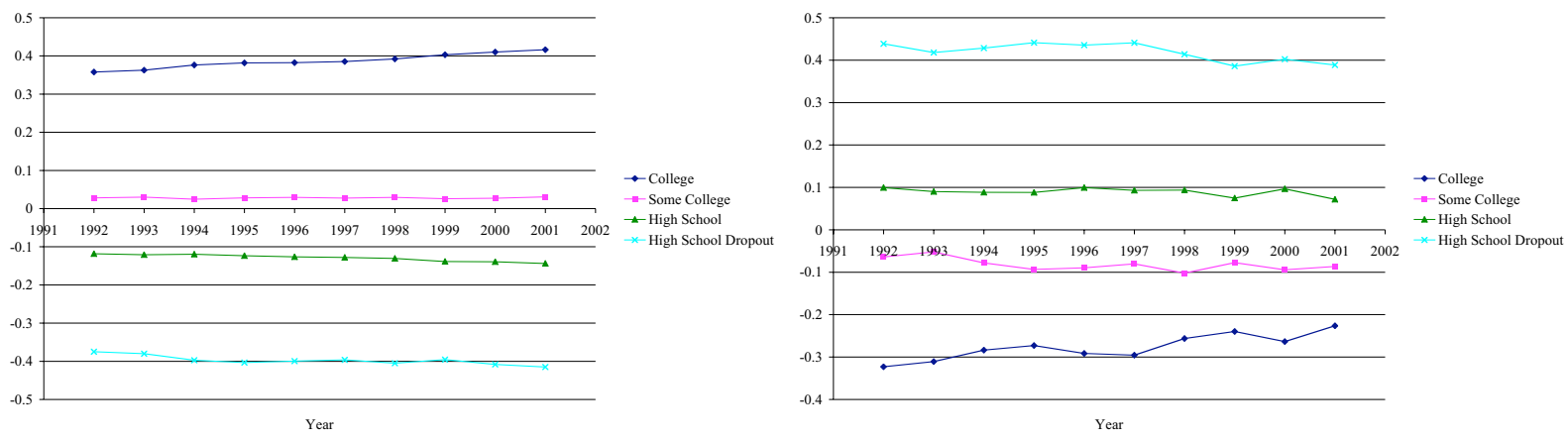

Figure 5b: British Wage and Unemployment Regression: Education Coefficients 1990s (BLFS)
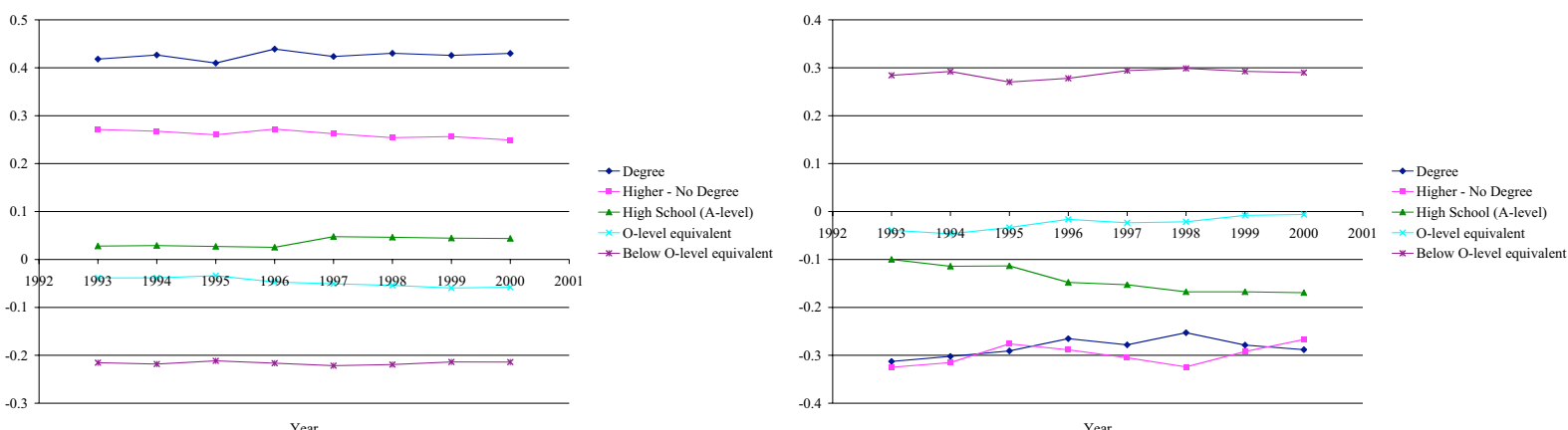

Figure 5c: German Wage and Unemployment Regression: Education Coefficients 1990s - (Wages: IABR; Unemployment: GLFS)
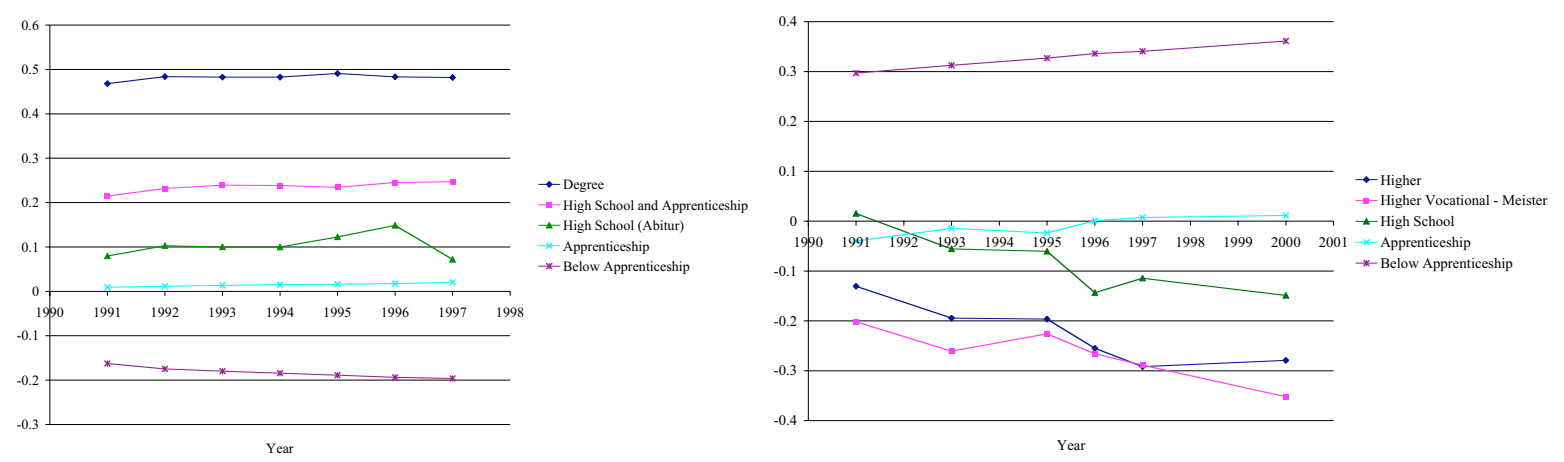

Note: The left and right panels exhibit the transformed wage and unemployment regression coefficients $\beta^{*}$ and $\gamma^{*}$, respectively.

Sources: Current Population Survey - Merged Outgoing Rotation Group Files (CPS); British Labour Force Survey (BLFS); German Labour Force Survey - Mikrozensus (GLFS); own calculations. 


\title{
Internet Appendix
}

\section{Transatlantic Differences in Labour Markets \\ Changes in Wage and Non-Employment Structures in the 1980s and the 1990s}

\author{
Patrick A. Puhani \\ Darmstadt University of Technology; SIAW, University of St. Gallen; \\ IZA, Bonn; WDI, Ann Arbor, MI
}

This Appendix includes only tables for the 1990s in order to demonstrate the regression results underlying the classifications reported in the paper.

The results for the 1980s are made available on request 
Table A1: Numbers of Observations

\begin{tabular}{|c|c|c|c|c|c|c|c|c|c|c|c|}
\hline & 1991 & 1992 & 1993 & 1994 & 1995 & 1996 & 1997 & 1998 & 1999 & 2000 & 2001 \\
\hline \multicolumn{12}{|l|}{$\overline{\text { U.S. (CPS) }}$} \\
\hline Wage Regression & 166,640 & 164,571 & 161,685 & 147,040 & 134,019 & 105,589 & 107,365 & 106,798 & 103,098 & 101,048 & 105,440 \\
\hline Unempl. Regression & 214,970 & 212,232 & 208,411 & 202,498 & 200,246 & 177,983 & 180,462 & 181,377 & 182,691 & 183,530 & 196,172 \\
\hline $\begin{array}{l}\text { Non-Empl. } \\
\text { Regression }\end{array}$ & 283,576 & 278,606 & 274,198 & 266,401 & 263,147 & 232,780 & 235,372 & 235,549 & 237,754 & 238,950 & 255,548 \\
\hline \multicolumn{12}{|l|}{ Britain (BLFS) } \\
\hline Wage Regression & & & 33,441 & 33,924 & 35,809 & 35,485 & 63,367 & 69,952 & 67,058 & 64,366 & \\
\hline Unempl. Regression & & & 283,381 & 279,782 & 282,896 & 274,108 & 260,728 & 262,232 & 258,136 & 253,360 & \\
\hline $\begin{array}{l}\text { Non-Empl. } \\
\text { Regression } \\
\text { Britain (BHPS) }\end{array}$ & & & 362,679 & 357,707 & 362,278 & 350,368 & 332,907 & 334,519 & 327,482 & 321,094 & \\
\hline Wage Regression & 4,355 & 4,085 & 3,922 & 3,971 & 3,975 & 4,132 & 4,254 & 4,230 & 4,140 & 3,974 & \\
\hline Unempl. Regression & 6,184 & 5,714 & 5,458 & 5,455 & 5,296 & 5,506 & 5,520 & 5,408 & 5,309 & 5,076 & \\
\hline $\begin{array}{l}\text { Non-Empl. } \\
\text { Regression }\end{array}$ & 8,056 & 7,598 & 7,269 & 7,225 & 7,036 & 7,314 & 7,289 & 7,005 & 6,866 & 6,553 & \\
\hline \multicolumn{12}{|l|}{ Germany (GSOEP) } \\
\hline Wage Regression & 3,969 & 3,852 & 3,877 & 3,747 & 4,007 & 3,898 & 3,789 & 3,949 & 4,100 & 7,258 & \\
\hline Unempl. Regression & 5,527 & 5,360 & 5,378 & 5,119 & 5,423 & 5,311 & 5,159 & 5,588 & 5,560 & 10,156 & \\
\hline $\begin{array}{l}\text { Non-Empl. } \\
\text { Regression } \\
\text { Germany (GLFS) }\end{array}$ & 7,567 & 7,462 & 7,393 & 7,215 & 7,633 & 7,335 & 7,126 & 7,723 & 7,559 & 14,013 & \\
\hline Wage Regression & 134,115 & & 131,774 & & 135,266 & 132,696 & 133,106 & & & 132,930 & \\
\hline Unempl. Regression & 169,287 & & 169,734 & & 176,098 & 171,260 & 174,199 & & & 170,346 & \\
\hline $\begin{array}{l}\text { Non-Empl. } \\
\text { Regression } \\
\text { Germany (IABR) }\end{array}$ & 238,321 & & 235,371 & & 244,291 & 239,708 & 242,307 & & & 234,421 & \\
\hline Wage Regression & 156,049 & 157,493 & 154,606 & 148,811 & 147,495 & 143,780 & 140,906 & & & & \\
\hline Unempl. Regression & 205,424 & 209,560 & 210,288 & 207,097 & 205,829 & 203,028 & 200,607 & & & & \\
\hline
\end{tabular}

Note: Changes between 1995 and 1996 in the CPS are explained by the changes in the imputation flags (cf. Hirsch and Schumacher, 2002). The large increase in the number of wage observations in the BLFS between 1996 and 1997 is explained by the fact that respondents were asked about their wage only in the $1^{\text {st }}$ quarter of interview up to 1996 , but also in the $5^{\text {th }}$ quarter since 1997. Columns with no entry signify that no data are available (to me) for these years.

Sources: Current Population Survey - Merged Outgoing Rotation Group Files (CPS); British Labour Force Survey (BLFS); British Household Panel Survey (BHPS); German Socio-Economic Panel (GSOEP); German Labour Force Survey - Mikrozensus (GLFS); German Adminsitrative Data - Institut für Arbeitsmarkt und Berufsforschung Regionalstichprobe (IABR); own calculations. 
Table A2: Unemployment Rates by Age

\begin{tabular}{|c|c|c|c|c|c|c|c|c|c|c|c|}
\hline Variable & 1991 & 1992 & 1993 & 1994 & 1995 & 1996 & 1997 & 1998 & 1999 & 2000 & 2001 \\
\hline \multicolumn{12}{|l|}{ U.S. (CPS) } \\
\hline Whole sample & 6.8 & 7.5 & 7.0 & 6.1 & 5.6 & 5.3 & 4.9 & 4.5 & 4.1 & 3.9 & 4.6 \\
\hline $16-25$ & 12.6 & 13.3 & 12.8 & 11.6 & 11.3 & 11.1 & 10.6 & 9.9 & 9.1 & 8.6 & 9.6 \\
\hline $26-35$ & 6.7 & 7.3 & 6.7 & 5.7 & 5.2 & 4.9 & 4.5 & 4.0 & 3.7 & 3.3 & 4.3 \\
\hline $36-45$ & 4.9 & 5.6 & 5.4 & 4.6 & 4.0 & 4.0 & 3.6 & 3.2 & 3.0 & 3.0 & 3.5 \\
\hline $46-55$ & 4.6 & 5.3 & 5.1 & 4.0 & 3.3 & 3.3 & 2.9 & 2.7 & 2.5 & 2.4 & 2.9 \\
\hline $56-65$ & 4.0 & 5.3 & 4.7 & 4.1 & 3.7 & 3.3 & 3.0 & 2.5 & 2.8 & 2.4 & 3.1 \\
\hline \multicolumn{12}{|l|}{$\overline{\text { Britain (BLFS) }}$} \\
\hline Whole sample & & & 10.4 & 9.6 & 8.7 & 8.1 & 7.0 & 6.3 & 6.0 & 5.5 & \\
\hline $16-25$ & & & 17.9 & 16.6 & 15.4 & 15.0 & 13.7 & 13.0 & 12.3 & 11.9 & \\
\hline $26-35$ & & & 10.0 & 9.2 & 8.4 & 7.9 & 6.5 & 5.9 & 5.6 & 4.8 & \\
\hline $36-45$ & & & 7.6 & 7.0 & 6.7 & 6.2 & 5.0 & 4.4 & 4.4 & 3.9 & \\
\hline $46-55$ & & & 7.5 & 6.9 & 6.1 & 5.3 & 4.6 & 4.0 & 4.0 & 3.6 & \\
\hline $56-65$ & & & 9.2 & 8.6 & 7.0 & 6.6 & 5.7 & 4.6 & 4.2 & 3.9 & \\
\hline \multicolumn{12}{|c|}{ Britain (BHPS) } \\
\hline Whole sample & 8.7 & 9.4 & 9.0 & 8.5 & 6.4 & 6.5 & 5.3 & 4.6 & 4.2 & 4.6 & \\
\hline $16-25$ & 16.1 & 17.7 & 17.8 & 16.0 & 12.8 & 13.2 & 12.1 & 11.2 & 10.0 & 10.6 & \\
\hline $26-35$ & 7.2 & 8.4 & 6.9 & 6.6 & 5.1 & 5.2 & 4.3 & 4.0 & 4.0 & 4.3 & \\
\hline $36-45$ & 4.8 & 6.1 & 7.1 & 6.6 & 4.4 & 4.2 & 3.3 & 2.5 & 2.2 & 2.6 & \\
\hline $46-55$ & 7.1 & 7.4 & 7.0 & 6.9 & 5.3 & 5.1 & 3.7 & 2.4 & 3.3 & 3.8 & \\
\hline $56-65$ & 10.8 & 8.8 & 8.1 & 10.5 & 7.5 & 8.2 & 6.0 & 6.0 & 3.8 & 4.5 & \\
\hline \multicolumn{12}{|c|}{$\overline{\text { Germany (GSOEP) }}$} \\
\hline Whole sample & 3.6 & 3.7 & 5.1 & 5.4 & 5.9 & 5.6 & 6.7 & 6.8 & 5.4 & 4.5 & \\
\hline $16-25$ & 5.1 & 4.3 & 9.6 & 12.0 & 11.1 & 12.8 & 13.2 & 14.2 & 13.3 & 11.6 & \\
\hline $26-35$ & 4.1 & 4.6 & 6.4 & 5.3 & 7.0 & 5.1 & 7.1 & 6.0 & 5.3 & 4.4 & \\
\hline $36-45$ & 3.5 & 3.6 & 3.2 & 4.1 & 4.5 & 4.7 & 6.2 & 7.9 & 4.7 & 3.5 & \\
\hline $46-55$ & 2.3 & 3.0 & 3.7 & 4.9 & 4.6 & 4.8 & 4.7 & 4.6 & 3.3 & 2.9 & \\
\hline $56-65$ & 2.0 & 2.2 & 2.5 & 1.8 & 2.1 & 3.0 & 4.1 & 3.3 & 3.1 & 2.6 & \\
\hline \multicolumn{12}{|c|}{ Germany (GLFS) } \\
\hline Whole sample & 3.2 & & 5.3 & & 5.8 & 6.4 & 7.1 & & & 5.0 & \\
\hline $16-25$ & 2.9 & & 5.6 & & 6.0 & 7.4 & 8.5 & & & 5.4 & \\
\hline $26-35$ & 3.4 & & 5.4 & & 5.4 & 5.9 & 6.5 & & & 4.2 & \\
\hline $36-45$ & 2.8 & & 4.6 & & 5.1 & 5.3 & 6.0 & & & 4.1 & \\
\hline $46-55$ & 3.1 & & 4.4 & & 5.7 & 5.9 & 6.6 & & & 5.2 & \\
\hline $56-65$ & 4.5 & & 8.5 & & 8.6 & 10.3 & 10.9 & & & 8.0 & \\
\hline \multicolumn{12}{|c|}{ Germany (IABR) } \\
\hline Whole sample & 4.7 & 5.3 & 7.2 & 8.6 & 8.5 & 9.4 & 9.7 & & & & \\
\hline $16-25$ & 3.1 & 3.9 & 5.6 & 7.1 & 6.3 & 7.4 & 7.8 & & & & \\
\hline $26-35$ & 4.6 & 5.0 & 6.9 & 8.0 & 7.2 & 8.1 & 8.6 & & & & \\
\hline $36-45$ & 3.8 & 4.1 & 5.4 & 6.4 & 6.4 & 7.2 & 8.1 & & & & \\
\hline $46-55$ & 4.0 & 4.4 & 5.8 & 7.4 & 7.4 & 8.1 & 8.6 & & & & \\
\hline $56-65$ & 15.5 & 16.2 & 20.6 & 22.1 & 23.1 & 22.9 & 20.5 & & & & \\
\hline
\end{tabular}

Note: The comparatively high youth unemployment rates in the GSOEP (when compared to GLFS and IABR) are explained by the lack of an 'active search' question in the GSOEP up to 1995 (although desire to work again and readiness to start work immediately are asked for all through the years). Using the 'search' question in 1996, for example, reduces the youth unemployment rate in the GSOEP from 12.8 to 8.9 percent. However, in oder to obtain a consistent definition over time, I have not used this variable for the years 1996 onward. Sampling weights are used wherever applicable.

Sources: CPS-MORG; BLFS; BHPS; GSOEP; GLFS; IABR; see also Table A1; own calculations. 
Table A3: Non-Employment Rates by Age

\begin{tabular}{|c|c|c|c|c|c|c|c|c|c|c|c|}
\hline Variable & 1991 & 1992 & 1993 & 1994 & 1995 & 1996 & 1997 & 1998 & 1999 & 2000 & 2001 \\
\hline \multicolumn{12}{|l|}{ U.S. (CPS) } \\
\hline Whole sample & 29.4 & 29.6 & 29.3 & 28.5 & 28.1 & 27.7 & 27.1 & 26.6 & 26.5 & 26.5 & 27.3 \\
\hline $16-25$ & 40.7 & 41.2 & 40.8 & 40.2 & 39.8 & 40.4 & 40.3 & 39.0 & 39.2 & 38.4 & 40.4 \\
\hline $26-35$ & 22.0 & 22.1 & 22.0 & 21.4 & 20.6 & 20.0 & 19.5 & 18.8 & 18.5 & 18.3 & 19.5 \\
\hline $36-45$ & 18.6 & 19.5 & 19.5 & 19.0 & 18.7 & 18.6 & 17.9 & 18.0 & 17.6 & 17.7 & 18.3 \\
\hline $46-55$ & 24.0 & 24.1 & 23.7 & 22.6 & 22.5 & 21.6 & 20.8 & 20.5 & 20.5 & 20.5 & 20.9 \\
\hline $56-65$ & 50.9 & 51.2 & 50.7 & 50.0 & 49.6 & 48.8 & 47.6 & 47.0 & 46.6 & 46.5 & 45.4 \\
\hline \multicolumn{12}{|l|}{ Britain (BLFS) } \\
\hline Whole sample & & & 29.8 & 29.1 & 28.4 & 27.8 & 26.9 & 26.3 & 25.6 & 25.1 & \\
\hline $16-25$ & & & 41.0 & 40.1 & 39.1 & 38.1 & 37.2 & 36.9 & 36.5 & 36.5 & \\
\hline $26-35$ & & & 25.7 & 24.7 & 24.0 & 23.5 & 21.9 & 21.2 & 20.1 & 19.5 & \\
\hline $36-45$ & & & 20.8 & 21.0 & 20.6 & 20.3 & 19.6 & 18.8 & 18.5 & 17.8 & \\
\hline $46-55$ & & & 25.2 & 24.5 & 24.0 & 23.3 & 23.0 & 22.9 & 22.4 & 22.0 & \\
\hline $56-65$ & & & 42.7 & 42.2 & 41.9 & 41.7 & 41.3 & 40.5 & 39.7 & 38.6 & \\
\hline \multicolumn{12}{|l|}{ Britain (BHPS) } \\
\hline Whole sample & 30.3 & 32.0 & 32.1 & 31.8 & 30.2 & 30.5 & 29.2 & 27.3 & 27.3 & 27.3 & \\
\hline $16-25$ & 36.3 & 41.4 & 41.8 & 41.7 & 41.0 & 40.9 & 38.9 & 33.7 & 33.7 & 35.0 & \\
\hline $26-35$ & 23.9 & 24.3 & 23.9 & 22.5 & 21.3 & 21.9 & 19.5 & 18.8 & 18.1 & 17.3 & \\
\hline $36-45$ & 17.5 & 20.0 & 21.5 & 20.3 & 18.7 & 17.1 & 16.4 & 16.2 & 15.1 & 16.6 & \\
\hline $46-55$ & 23.5 & 24.1 & 22.6 & 23.9 & 23.8 & 24.4 & 24.2 & 21.9 & 22.1 & 23.0 & \\
\hline $56-65$ & 56.6 & 58.0 & 59.4 & 60.7 & 56.4 & 59.1 & 58.2 & 56.6 & 57.0 & 54.2 & \\
\hline \multicolumn{12}{|c|}{ Germany (GSOEP) } \\
\hline Whole sample & 30.6 & 31.7 & 31.8 & 34.2 & 33.9 & 32.3 & 32.5 & 33.0 & 31.0 & 30.7 & \\
\hline $16-25$ & 33.7 & 35.5 & 38.3 & 43.9 & 42.9 & 40.4 & 38.8 & 41.3 & 38.2 & 35.7 & \\
\hline $26-35$ & 21.8 & 23.8 & 24.5 & 24.9 & 24.6 & 23.3 & 24.6 & 25.7 & 23.0 & 23.0 & \\
\hline $36-45$ & 20.5 & 19.4 & 17.6 & 20.9 & 21.8 & 19.3 & 20.7 & 19.7 & 16.2 & 16.8 & \\
\hline $46-55$ & 21.0 & 24.4 & 26.7 & 29.0 & 27.4 & 26.5 & 24.0 & 23.6 & 22.7 & 20.0 & \\
\hline $56-65$ & 62.5 & 63.3 & 60.2 & 60.8 & 61.1 & 60.8 & 64.0 & 63.3 & 61.0 & 62.9 & \\
\hline \multicolumn{12}{|c|}{ Germany (GLFS) } \\
\hline Whole sample & 31.2 & & 31.7 & & 32.1 & 33.1 & 33.2 & & & 31.0 & \\
\hline $16-25$ & 29.6 & & 29.8 & & 31.3 & 34.2 & 34.8 & & & 31.3 & \\
\hline $26-35$ & 23.0 & & 24.2 & & 23.9 & 25.7 & 25.5 & & & 22.3 & \\
\hline $36-45$ & 19.0 & & 19.4 & & 19.8 & 20.4 & 20.6 & & & 17.4 & \\
\hline $46-55$ & 25.4 & & 25.2 & & 25.5 & 25.5 & 25.3 & & & 22.5 & \\
\hline $56-65$ & 65.1 & & 65.1 & & 65.0 & 64.9 & 64.4 & & & 65.1 & \\
\hline
\end{tabular}

Note: The differerence in the non-employment rates for young people in the German GSOEP and GLFS data sets stems from the fact that certain groups like conscripts or mothers on maternity leave cannot be treated consistently over time in the same way across these two data sets. Sampling weights are used wherever applicable.

Sources: Current Population Survey - Merged Outgoing Rotation Group Files (CPS); British Labour Force Survey (BLFS); British Household Panel Survey (BHPS); German Socio-Economic Panel (GSOEP); German Labour Force Survey - Mikrozensus (GLFS); German Adminsitrative Data - Institut für Arbeitsmarkt und Berufsforschung Regionalstichprobe (IABR); own calculations. 
Table A4: Unemployment Rates by Education

\begin{tabular}{|c|c|c|c|c|c|c|c|c|c|c|c|}
\hline Variable & 1991 & 1992 & 1993 & 1994 & 1995 & 1996 & 1997 & 1998 & 1999 & 2000 & 2001 \\
\hline \multicolumn{12}{|l|}{ U.S. (CPS) } \\
\hline Whole sample & 6.8 & 7.5 & 7.0 & 6.1 & 5.6 & 5.3 & 4.9 & 4.5 & 4.1 & 3.9 & 4.6 \\
\hline College Degree & 3.0 & 3.3 & 3.2 & 2.8 & 2.5 & 2.3 & 2.0 & 2.0 & 1.9 & 1.7 & 2.4 \\
\hline Some College & 5.8 & 6.3 & 6.1 & 5.0 & 4.4 & 4.2 & 3.9 & 3.4 & 3.4 & 3.0 & 3.8 \\
\hline High School & 6.9 & 8.2 & 7.7 & 6.6 & 6.0 & 5.9 & 5.4 & 5.0 & 4.5 & 4.4 & 5.1 \\
\hline High School Dropout & 14.1 & 15.6 & 14.8 & 13.6 & 13.2 & 12.6 & 12.0 & 10.9 & 9.9 & 9.6 & 10.9 \\
\hline \multicolumn{12}{|l|}{ Britain (BLFS) } \\
\hline Whole sample & & & 10.4 & 9.6 & 8.7 & 8.1 & 7.0 & 6.3 & 6.0 & 5.5 & \\
\hline Degree & & & 5.4 & 5.1 & 4.8 & 4.7 & 3.8 & 3.5 & 3.2 & 2.8 & \\
\hline Higher - No Degree & & & 4.7 & 4.5 & 4.5 & 4.0 & 3.3 & 2.8 & 2.9 & 2.8 & \\
\hline High School (A-level) & & & 9.1 & 8.2 & 7.5 & 6.5 & 5.5 & 4.8 & 4.6 & 4.2 & \\
\hline O-level equivalent & & & 10.2 & 9.3 & 8.7 & 8.6 & 7.4 & 6.8 & 6.7 & 6.3 & \\
\hline Below O-level equivalent & & & 14.7 & 13.9 & 12.4 & 11.9 & 10.7 & 9.8 & 9.4 & 8.7 & \\
\hline \multicolumn{12}{|l|}{ Britain (BHPS) } \\
\hline Whole sample & 8.7 & 9.4 & 9.0 & 8.5 & 6.4 & 6.5 & 5.3 & 4.6 & 4.2 & 4.6 & \\
\hline Degree & 3.8 & 5.4 & 5.4 & 5.3 & 5.1 & 4.7 & 4.7 & 3.0 & 3.1 & 2.3 & \\
\hline Higher - No Degree & 3.4 & 3.5 & 4.5 & 4.0 & 3.3 & 1.2 & 3.1 & 4.2 & 1.8 & 3.7 & \\
\hline High School (A-level) & 6.4 & 6.9 & 6.0 & 7.1 & 4.1 & 4.8 & 4.1 & 3.4 & 3.0 & 3.4 & \\
\hline O-level equivalent & 7.8 & 7.9 & 7.8 & 6.4 & 6.8 & 6.1 & 4.7 & 4.0 & 4.1 & 4.1 & \\
\hline Below O-level equivalent & 13.5 & 15.0 & 14.9 & 13.9 & 10.0 & 11.0 & 8.4 & 8.2 & 7.9 & 9.5 & \\
\hline \multicolumn{12}{|l|}{ Germany (GSOEP) } \\
\hline Whole sample & 3.6 & 3.7 & 5.1 & 5.4 & 5.9 & 5.6 & 6.7 & 6.8 & 5.4 & 4.5 & \\
\hline Degree & 3.3 & 2.1 & 2.7 & 4.2 & 4.6 & 5.9 & 3.0 & 5.5 & 2.5 & 3.4 & \\
\hline Higher - No Degree & 4.5 & 1.5 & 1.3 & 2.7 & 2.7 & 4.5 & 7.3 & 3.3 & 2.1 & 3.8 & \\
\hline High School - Abitur & 5.0 & 6.8 & 9.7 & 5.4 & 11.1 & 9.8 & 8.8 & 11.7 & 10.0 & 8.9 & \\
\hline Apprenticeship & 2.6 & 3.5 & 4.9 & 5.3 & 5.1 & 4.2 & 6.2 & 6.0 & 4.3 & 3.1 & \\
\hline Below Apprenticeship & 5.8 & 5.7 & 7.9 & 7.9 & 9.3 & 9.5 & 10.2 & 10.7 & 11.3 & 10.2 & \\
\hline \multicolumn{12}{|l|}{ Germany (GLFS) } \\
\hline Whole sample & 3.2 & & 5.3 & & 5.8 & 6.4 & 7.1 & & & 5.0 & \\
\hline Degree & 2.2 & & 3.3 & & 3.8 & 3.7 & 3.9 & & & 2.6 & \\
\hline Meister & 1.8 & & 2.9 & & 3.5 & 3.7 & 4.0 & & & 2.2 & \\
\hline High School & 3.2 & & 4.7 & & 5.0 & 4.6 & 5.6 & & & 3.4 & \\
\hline Apprenticeship & 2.8 & & 4.9 & & 5.4 & 6.2 & 7.1 & & & 4.9 & \\
\hline Below Apprenticeship & 5.6 & & 9.3 & & 10.5 & 11.4 & 12.9 & & & 9.4 & \\
\hline \multicolumn{12}{|l|}{ Germany (IABR) } \\
\hline Whole sample & 4.7 & 5.3 & 7.2 & 8.6 & 8.5 & 9.4 & 9.7 & & & & \\
\hline Degree & 2.9 & 3.0 & 3.5 & 4.5 & 4.5 & 5.4 & 5.5 & & & & \\
\hline High School and Apprenticeship & 3.3 & 3.0 & 3.8 & 4.7 & 4.1 & 4.7 & 5.0 & & & & \\
\hline High School (Abitur) & 3.1 & 3.5 & 4.9 & 5.9 & 4.8 & 5.7 & 5.9 & & & & \\
\hline Apprenticeship & 4.0 & 4.5 & 6.3 & 7.5 & 7.5 & 8.2 & 8.5 & & & & \\
\hline Below Apprenticeship & 7.0 & 8.1 & 11.2 & 13.7 & 13.5 & 14.8 & 15.4 & & & & \\
\hline
\end{tabular}

Note: Sampling weights are used wherever applicable.

Sources: Current Population Survey - Merged Outgoing Rotation Group Files (CPS); British Labour Force Survey (BLFS); British Household Panel Survey (BHPS); German Socio-Economic Panel (GSOEP); German Labour Force Survey - Mikrozensus (GLFS); German Adminsitrative Data - Institut für Arbeitsmarkt und Berufsforschung Regionalstichprobe (IABR); own calculations. 
Table A5: Non-Employment Rates by Education

\begin{tabular}{|c|c|c|c|c|c|c|c|c|c|c|c|}
\hline Variable & 1991 & 1992 & 1993 & 1994 & 1995 & 1996 & 1997 & 1998 & 1999 & 2000 & 2001 \\
\hline \multicolumn{12}{|l|}{ U.S. (CPS) } \\
\hline Whole sample & 29.4 & 29.6 & 29.3 & 28.5 & 28.1 & 27.7 & 27.1 & 26.6 & 26.5 & 26.5 & 27.3 \\
\hline College Degree & 14.7 & 14.9 & 14.8 & 14.5 & 14.5 & 14.5 & 14.2 & 14.4 & 14.9 & 15.1 & 15.9 \\
\hline Some College & 25.0 & 24.6 & 24.4 & 23.2 & 22.7 & 22.6 & 22.4 & 21.7 & 22.1 & 22.1 & 22.9 \\
\hline High School & 27.6 & 29.4 & 29.4 & 28.7 & 28.3 & 27.6 & 27.0 & 27.0 & 26.8 & 27.0 & 27.7 \\
\hline High School Dropout & 51.9 & 53.7 & 53.8 & 53.4 & 52.9 & 52.5 & 51.3 & 50.0 & 49.8 & 49.2 & 51.2 \\
\hline \multicolumn{12}{|l|}{ Britain (BLFS) } \\
\hline Whole sample & & & 29.8 & 29.1 & 28.4 & 27.8 & 26.9 & 26.3 & 25.6 & 25.1 & \\
\hline Degree & & & 14.7 & 13.8 & 13.6 & 13.5 & 12.8 & 12.9 & 12.5 & 11.8 & \\
\hline Higher - No Degree & & & 17.0 & 16.5 & 16.7 & 16.3 & 15.1 & 15.0 & 14.5 & 14.4 & \\
\hline High School (A-level) & & & 24.9 & 24.6 & 24.1 & 22.9 & 22.3 & 21.8 & 21.1 & 20.7 & \\
\hline O-level equivalent & & & 29.1 & 28.0 & 27.5 & 26.8 & 25.9 & 24.9 & 24.8 & 24.7 & \\
\hline Below O-level equivalent & & & 39.9 & 39.9 & 39.1 & 39.3 & 38.9 & 38.7 & 38.6 & 38.5 & \\
\hline \multicolumn{12}{|l|}{ Britain (BHPS) } \\
\hline Whole sample & 30.3 & 32.0 & 32.1 & 31.8 & 30.2 & 30.5 & 29.2 & 27.3 & 27.3 & 27.3 & \\
\hline Degree & 13.3 & 15.7 & 15.3 & 17.1 & 14.6 & 17.2 & 15.7 & 14.3 & 15.2 & 14.6 & \\
\hline Higher - No Degree & 22.6 & 26.3 & 25.9 & 26.0 & 25.6 & 24.3 & 24.7 & 24.8 & 24.6 & 26.9 & \\
\hline High School (A-level) & 21.7 & 24.4 & 24.7 & 25.2 & 24.2 & 23.8 & 22.1 & 19.0 & 19.3 & 19.9 & \\
\hline O-level equivalent & 27.2 & 28.3 & 30.0 & 29.1 & 29.8 & 30.2 & 28.4 & 27.2 & 27.1 & 27.9 & \\
\hline Below O-level equivalent & 41.9 & 44.2 & 44.5 & 44.2 & 42.1 & 43.2 & 43.6 & 43.8 & 44.1 & 44.8 & \\
\hline \multicolumn{12}{|l|}{$\begin{array}{l}\text { Germany (GSOEP) } \\
\text { (GSO }\end{array}$} \\
\hline Whole sample & 30.6 & 31.7 & 31.8 & 34.2 & 33.9 & 32.3 & 32.5 & 33.0 & 31.0 & 30.7 & \\
\hline Degree & 16.0 & 14.6 & 14.8 & 15.4 & 15.0 & 15.0 & 13.3 & 15.1 & 11.9 & 14.7 & \\
\hline Higher - No Degree & 22.4 & 23.4 & 19.0 & 23.5 & 24.8 & 24.2 & 24.9 & 25.0 & 20.4 & 22.4 & \\
\hline High School - Abitur & 49.5 & 48.5 & 49.5 & 45.6 & 43.8 & 43.2 & 39.3 & 45.6 & 43.7 & 45.2 & \\
\hline Apprenticeship & 26.9 & 27.5 & 28.4 & 30.2 & 30.4 & 29.1 & 30.6 & 30.7 & 28.8 & 29.5 & \\
\hline Below Apprenticeship & 43.0 & 46.5 & 46.2 & 51.2 & 50.4 & 48.6 & 46.7 & 47.2 & 46.7 & 45.8 & \\
\hline \multicolumn{12}{|l|}{ Germany (GLFS) } \\
\hline Whole sample & 31.2 & & 31.7 & & 32.1 & 33.1 & 33.2 & & & 31.0 & \\
\hline Degree & 15.0 & & 15.3 & & 15.8 & 16.5 & 16.8 & & & 15.9 & \\
\hline Meister & 16.0 & & 16.1 & & 16.9 & 18.7 & 19.3 & & & 17.3 & \\
\hline High School & 50.2 & & 50.0 & & 46.0 & 44.3 & 42.8 & & & 37.2 & \\
\hline Apprenticeship & 26.1 & & 27.4 & & 28.6 & 29.9 & 30.9 & & & 29.6 & \\
\hline No Prof Training & 47.1 & & 47.1 & & 49.3 & 49.7 & 50.2 & & & 45.4 & \\
\hline
\end{tabular}

Note: Sampling weights are used wherever applicable.

Sources: Current Population Survey - Merged Outgoing Rotation Group Files (CPS); British Labour Force Survey (BLFS); British Household Panel Survey (BHPS); German Socio-Economic Panel (GSOEP); German Labour Force Survey - Mikrozensus (GLFS); German Adminsitrative Data - Institut für Arbeitsmarkt und Berufsforschung Regionalstichprobe (IABR); own calculations. 
Table A6: U.S. and British Wage Regressions (Changes in Transformed Age Coefficients with Respect to the Base Year - Corresponding t-values in Parentheses)

\begin{tabular}{|c|c|c|c|c|c|c|c|c|c|c|}
\hline & 1992 & 1993 & 1994 & 1995 & 1996 & 1997 & 1998 & 1999 & 2000 & 2001 \\
\hline \multicolumn{11}{|c|}{ U.S. (CPS; Base 1992) } \\
\hline \multirow[t]{2}{*}{$16-25$} & & -0.01 & 0.00 & 0.00 & 0.01 & 0.02 & 0.03 & 0.04 & 0.06 & 0.06 \\
\hline & & $-(1.8)$ & $-(1.2)$ & $(0.3)$ & $(2.1)$ & $(4.5)$ & $(6.5)$ & $(10.0)$ & (13.7) & (13.3) \\
\hline \multirow[t]{2}{*}{$26-35$} & & 0.00 & -0.01 & -0.01 & -0.01 & -0.01 & -0.01 & -0.02 & 0.00 & 0.00 \\
\hline & & $-(0.1)$ & $-(4.0)$ & $-(3.0)$ & $-(3.1)$ & $-(4.0)$ & $-(2.8)$ & $-(4.6)$ & $-(1.3)$ & $-(1.2)$ \\
\hline \multirow[t]{2}{*}{$36-45$} & & 0.00 & 0.01 & 0.01 & 0.00 & 0.01 & 0.00 & -0.01 & -0.01 & -0.01 \\
\hline & & $(1.3)$ & $(2.9)$ & $(2.3)$ & $(0.9)$ & $(1.7)$ & $(0.4)$ & $-(1.6)$ & $-(1.8)$ & $-(1.7)$ \\
\hline \multirow{2}{*}{\multicolumn{2}{|c|}{$46-55$}} & 0.00 & 0.01 & 0.00 & 0.00 & -0.01 & -0.02 & -0.02 & -0.03 & -0.04 \\
\hline & & $-(0.2)$ & $(1.5)$ & $-(0.4)$ & $(0.4)$ & $-(2.6)$ & $-(3.7)$ & $-(3.4)$ & $-(6.5)$ & $-(7.5)$ \\
\hline \multirow{2}{*}{\multicolumn{2}{|c|}{$56-65$}} & 0.00 & 0.01 & 0.01 & 0.00 & 0.01 & 0.00 & 0.01 & -0.03 & -0.02 \\
\hline & & $(0.7)$ & $(1.2)$ & $(1.1)$ & $(0.3)$ & $(1.2)$ & $(0.3)$ & $(0.9)$ & $-(3.6)$ & $-(2.3)$ \\
\hline \multicolumn{11}{|c|}{ Britain (BLFS; Base 1993) } \\
\hline \multirow[t]{2}{*}{$16-25$} & & & -0.02 & -0.04 & -0.05 & -0.06 & -0.06 & -0.06 & -0.05 & \\
\hline & & & $-(2.5)$ & $-(4.3)$ & $-(6.2)$ & $-(7.8)$ & $-(7.7)$ & $-(7.1)$ & $-(6.8)$ & \\
\hline \multirow[t]{2}{*}{$26-35$} & & & 0.00 & 0.01 & 0.02 & 0.02 & 0.02 & 0.02 & 0.01 & \\
\hline & & & $(0.4)$ & $(2.1)$ & $(2.8)$ & $(3.6)$ & $(3.0)$ & $(3.5)$ & $(2.4)$ & \\
\hline \multirow[t]{2}{*}{$36-45$} & & & 0.00 & 0.01 & 0.01 & 0.00 & 0.00 & 0.00 & 0.01 & \\
\hline & & & $-(0.5)$ & $(0.9)$ & $(0.8)$ & $(0.6)$ & $(0.8)$ & $(0.8)$ & $(1.3)$ & \\
\hline \multirow[t]{2}{*}{$46-55$} & & & 0.02 & 0.01 & 0.02 & 0.02 & 0.02 & 0.02 & 0.01 & \\
\hline & & & $(2.1)$ & $(1.1)$ & $(2.2)$ & $(3.4)$ & $(3.5)$ & (2.4) & $(2.1)$ & \\
\hline \multirow[t]{2}{*}{$56-65$} & & & 0.01 & 0.01 & 0.02 & 0.01 & 0.02 & 0.02 & 0.03 & \\
\hline & & & $(0.9)$ & $(0.6)$ & $(1.2)$ & $(1.1)$ & $(1.6)$ & $(1.4)$ & $(2.0)$ & \\
\hline \multicolumn{11}{|c|}{ Britain (BHPS; Base 1991) } \\
\hline \multirow[t]{2}{*}{$16-25$} & 0.02 & 0.00 & -0.02 & 0.00 & -0.05 & -0.05 & -0.04 & -0.02 & -0.02 & \\
\hline & $(1.0)$ & $(0.0)$ & $-(1.0)$ & $-(0.1)$ & $-(2.3)$ & $-(2.1)$ & $-(2.0)$ & $-(0.9)$ & $-(0.8)$ & \\
\hline \multirow[t]{2}{*}{$26-35$} & 0.00 & 0.00 & 0.01 & 0.00 & 0.00 & 0.01 & 0.00 & -0.01 & 0.00 & \\
\hline & $-(0.3)$ & $-(0.3)$ & $(1.0)$ & $(0.3)$ & $-(0.1)$ & $(0.5)$ & $-(0.2)$ & $-(0.5)$ & $(0.1)$ & \\
\hline \multirow[t]{2}{*}{$36-45$} & -0.02 & -0.01 & -0.01 & 0.01 & 0.01 & 0.03 & 0.02 & 0.03 & 0.02 & \\
\hline & $-(1.6)$ & $-(0.8)$ & $-(0.6)$ & $(0.5)$ & $(0.9)$ & $(1.5)$ & $(1.5)$ & $(1.7)$ & $(1.4)$ & \\
\hline \multirow[t]{2}{*}{$46-55$} & 0.01 & 0.01 & 0.00 & -0.02 & 0.04 & 0.01 & 0.01 & 0.01 & 0.02 & \\
\hline & $(0.6)$ & $(0.8)$ & $-(0.2)$ & $-(0.8)$ & (1.9) & $(0.7)$ & $(0.5)$ & $(0.7)$ & $(0.8)$ & \\
\hline \multirow[t]{2}{*}{$56-65$} & 0.00 & 0.01 & 0.03 & 0.00 & 0.00 & -0.01 & 0.01 & -0.04 & -0.07 & \\
\hline & $(0.1)$ & $(0.4)$ & $(0.8)$ & $(0.0)$ & $(0.0)$ & $-(0.4)$ & $(0.3)$ & $-(1.1)$ & $-(1.8)$ & \\
\hline
\end{tabular}

Note: $t$-values are based on standard errors allowing for clustering wherever applicable. Estimates use sampling weights wherever applicable.

Sources: Current Population Survey - Merged Outgoing Rotation Group Files (CPS); British Labour Force Survey (BLFS); British Household Panel Survey (BHPS); own calculations. 
Table A7: German Wage Regressions (Changes in Transformed Age Coefficients with Respect to 1991 - Corresponding t-values in Parentheses)

\begin{tabular}{|c|c|c|c|c|c|c|c|c|c|}
\hline & 1992 & 1993 & 1994 & 1995 & 1996 & 1997 & 1998 & 1999 & 2000 \\
\hline \multicolumn{10}{|c|}{ Germany (GSOEP) } \\
\hline \multirow[t]{2}{*}{$16-25$} & $(0.0)$ & $(1.3)$ & $-(0.8)$ & $-(1.3)$ & $-(1.2)$ & $-(2.7)$ & $-(4.0)$ & $-(3.0)$ & $-(2.5)$ \\
\hline & -0.01 & -0.02 & 0.01 & 0.01 & 0.01 & 0.02 & 0.01 & 0.01 & 0.00 \\
\hline \multirow[t]{2}{*}{$26-35$} & $-(0.4)$ & $-(1.4)$ & $(0.6)$ & $(0.6)$ & $(0.8)$ & $(1.2)$ & $(0.8)$ & $(0.8)$ & $-(0.2)$ \\
\hline & 0.00 & 0.00 & 0.01 & 0.02 & 0.01 & 0.01 & 0.03 & 0.00 & 0.01 \\
\hline \multirow[t]{2}{*}{$36-45$} & $(0.1)$ & $-(0.3)$ & $(0.7)$ & $(1.3)$ & $(0.3)$ & $(0.5)$ & $(1.8)$ & $(0.0)$ & $(0.6)$ \\
\hline & -0.01 & 0.01 & -0.01 & -0.02 & 0.00 & 0.00 & -0.01 & 0.00 & 0.00 \\
\hline \multirow[t]{2}{*}{$46-55$} & $-(0.7)$ & $(0.3)$ & $-(0.8)$ & $-(0.9)$ & $-(0.1)$ & $(0.1)$ & $-(0.5)$ & $(0.1)$ & $-(0.1)$ \\
\hline & 0.04 & 0.01 & 0.01 & 0.03 & 0.04 & 0.04 & 0.10 & 0.10 & 0.08 \\
\hline \multirow[t]{2}{*}{$56-65$} & $(1.2)$ & $(0.4)$ & $(0.2)$ & $(0.6)$ & $(1.0)$ & $(0.8)$ & $(2.1)$ & $(2.3)$ & $(2.2)$ \\
\hline & 0.00 & 0.01 & -0.02 & -0.06 & -0.05 & -0.10 & -0.12 & -0.06 & -0.07 \\
\hline \multicolumn{10}{|c|}{ Germany (GLFS) } \\
\hline \multirow[t]{2}{*}{$16-25$} & & 0.00 & & -0.01 & -0.02 & -0.03 & & & -0.02 \\
\hline & & $-(0.3)$ & & $-(2.1)$ & $-(4.0)$ & $-(7.1)$ & & & $-(5.6)$ \\
\hline \multirow[t]{2}{*}{$26-35$} & & -0.01 & & -0.02 & -0.01 & -0.01 & & & -0.01 \\
\hline & & $-(3.1)$ & & $-(6.8)$ & $-(2.9)$ & $-(1.9)$ & & & $-(3.1)$ \\
\hline \multirow[t]{2}{*}{$36-45$} & & 0.00 & & 0.00 & 0.00 & -0.01 & & & -0.01 \\
\hline & & $(0.9)$ & & $(1.1)$ & $-(1.7)$ & $-(1.7)$ & & & $-(4.9)$ \\
\hline \multirow[t]{2}{*}{$46-55$} & & 0.01 & & 0.02 & 0.01 & 0.02 & & & 0.01 \\
\hline & & $(2.8)$ & & $(6.1)$ & $(4.2)$ & $(6.1)$ & & & (3.2) \\
\hline \multirow[t]{2}{*}{$56-65$} & & 0.00 & & 0.01 & 0.04 & 0.04 & & & 0.09 \\
\hline & & $-(0.5)$ & & $(2.6)$ & $(6.5)$ & $(7.2)$ & & & $(15.8)$ \\
\hline \multicolumn{10}{|c|}{ Germany (IABR) } \\
\hline \multirow[t]{2}{*}{$16-25$} & 0.03 & 0.02 & 0.02 & 0.02 & 0.01 & -0.01 & & & \\
\hline & (11.8) & $(8.8)$ & (5.2) & $(5.2)$ & $(3.4)$ & $-(2.1)$ & & & \\
\hline \multirow[t]{2}{*}{$26-35$} & -0.01 & 0.00 & 0.00 & -0.01 & -0.01 & 0.00 & & & \\
\hline & $-(4.2)$ & $-(2.0)$ & $-(2.3)$ & $-(3.3)$ & $-(2.5)$ & $-(0.6)$ & & & \\
\hline \multirow[t]{2}{*}{$36-45$} & -0.01 & -0.01 & -0.01 & -0.01 & -0.01 & -0.01 & & & \\
\hline & $-(7.8)$ & $-(7.1)$ & $-(6.2)$ & $-(5.6)$ & $-(5.3)$ & $-(2.5)$ & & & \\
\hline \multirow[t]{2}{*}{$46-55$} & -0.01 & 0.00 & 0.00 & 0.00 & 0.01 & 0.01 & & & \\
\hline & $-(3.4)$ & $-(1.4)$ & $(1.6)$ & $(1.9)$ & (1.9) & (2.9) & & & \\
\hline \multirow[t]{2}{*}{$56-65$} & 0.01 & 0.00 & 0.00 & 0.01 & 0.02 & 0.02 & & & \\
\hline & (1.3) & $-(0.2)$ & $(0.9)$ & $(1.2)$ & $(2.6)$ & $(4.2)$ & & & \\
\hline
\end{tabular}

Note: $t$-values are based on standard errors allowing for clustering wherever applicable. Estimates use sampling weights wherever applicable.

Sources: German Socio-Economic Panel (GSOEP); German Labour Force Survey - Mikrozensus (GLFS); German Adminsitrative Data - Institut für Arbeitsmarkt und Berufsforschung Regionalstichprobe (IABR); own calculations. 
Table A8: U.S. and British Unemployment Regressions (Changes in Transformed Age Coefficients with Respect to the Base Year - Corresponding t-values in Parentheses)

\begin{tabular}{|c|c|c|c|c|c|c|c|c|c|c|}
\hline & 1992 & 1993 & 1994 & 1995 & 1996 & 1997 & 1998 & 1999 & 2000 & 2001 \\
\hline \multicolumn{11}{|c|}{ U.S. (CPS; Base 1992) } \\
\hline $16-25$ & & $\begin{array}{l}0.01 \\
(0.8)\end{array}$ & $\begin{array}{c}0.02 \\
(1.7)\end{array}$ & $\begin{array}{l}0.05 \\
(3.7)\end{array}$ & $\begin{array}{l}0.05 \\
(3.8)\end{array}$ & $\begin{array}{l}0.06 \\
(4.6)\end{array}$ & $\begin{array}{l}0.08 \\
(5.3)\end{array}$ & $\begin{array}{l}0.06 \\
(4.3)\end{array}$ & $\begin{array}{l}0.06 \\
(3.8)\end{array}$ & $\begin{array}{l}0.04 \\
(2.5)\end{array}$ \\
\hline \multirow[t]{2}{*}{$26-35$} & & -0.02 & -0.02 & -0.01 & -0.02 & -0.01 & -0.03 & -0.03 & -0.05 & -0.02 \\
\hline & & $-(1.7)$ & $-(1.7)$ & $-(0.7)$ & $-(1.5)$ & $-(1.2)$ & $-(2.1)$ & $-(2.7)$ & $-(4.0)$ & $-(1.9)$ \\
\hline \multirow[t]{2}{*}{$36-45$} & & 0.01 & 0.01 & 0.00 & 0.00 & 0.00 & -0.01 & -0.02 & 0.01 & -0.01 \\
\hline & & $(0.5)$ & $(0.6)$ & $-(0.3)$ & $(0.1)$ & $-(0.1)$ & $-(1.0)$ & $-(1.2)$ & $(0.9)$ & $-(0.7)$ \\
\hline \multirow{2}{*}{\multicolumn{2}{|c|}{$46-55$}} & 0.02 & -0.01 & -0.05 & -0.02 & -0.04 & -0.01 & -0.01 & 0.00 & -0.01 \\
\hline & & $(1.2)$ & $-(0.5)$ & $-(2.6)$ & $-(1.1)$ & $-(2.1)$ & $-(0.4)$ & $-(0.6)$ & $(0.1)$ & $-(0.4)$ \\
\hline \multirow{2}{*}{\multicolumn{2}{|c|}{$56-65$}} & -0.01 & 0.01 & 0.02 & -0.02 & -0.01 & -0.02 & 0.05 & 0.02 & 0.04 \\
\hline & & $-(0.6)$ & $(0.3)$ & $(0.7)$ & $-(0.8)$ & $-(0.5)$ & $-(0.8)$ & $(1.9)$ & $(0.5)$ & $(1.7)$ \\
\hline \multicolumn{11}{|c|}{ Britain (BLFS; Base 1993) } \\
\hline \multirow[t]{2}{*}{$16-25$} & & & 0.00 & 0.00 & 0.02 & 0.05 & 0.07 & 0.06 & 0.09 & \\
\hline & & & $-(0.4)$ & $-(0.2)$ & $(1.7)$ & $(3.5)$ & $(5.4)$ & $(4.0)$ & $(5.9)$ & \\
\hline \multirow[t]{2}{*}{$26-35$} & & & 0.00 & -0.01 & 0.00 & -0.02 & -0.01 & -0.02 & -0.04 & \\
\hline & & & $-(0.4)$ & $-(0.5)$ & $-(0.2)$ & $-(1.5)$ & $-(0.7)$ & $-(1.2)$ & $-(3.2)$ & \\
\hline \multirow[t]{2}{*}{$36-45$} & & & 0.00 & 0.03 & 0.02 & 0.01 & 0.00 & 0.01 & 0.01 & \\
\hline & & & $(0.4)$ & $(2.1)$ & $(1.8)$ & $(0.5)$ & $(0.2)$ & $(1.0)$ & $(0.9)$ & \\
\hline \multirow[t]{2}{*}{$46-55$} & & & 0.00 & -0.01 & -0.04 & -0.02 & -0.04 & -0.01 & -0.01 & \\
\hline & & & $(0.0)$ & $-(0.5)$ & $-(2.4)$ & $-(1.3)$ & $-(2.2)$ & $-(0.5)$ & $-(0.5)$ & \\
\hline \multirow[t]{2}{*}{$56-65$} & & & 0.01 & -0.03 & -0.02 & -0.02 & -0.06 & -0.09 & -0.07 & \\
\hline & & & $(0.6)$ & $-(1.4)$ & $-(0.9)$ & $-(0.9)$ & $-(2.3)$ & $-(3.4)$ & $-(2.6)$ & \\
\hline \multicolumn{11}{|c|}{ Britain (BHPS; Base 1991) } \\
\hline \multirow[t]{2}{*}{$16-25$} & 0.02 & 0.03 & -0.05 & -0.05 & -0.05 & 0.04 & 0.07 & 0.03 & 0.01 & \\
\hline & $(0.3)$ & $(0.5)$ & $-(0.7)$ & $-(0.8)$ & $-(0.7)$ & $(0.5)$ & $(0.9)$ & $(0.4)$ & $(0.1)$ & \\
\hline \multirow[t]{2}{*}{$26-35$} & 0.02 & -0.07 & -0.07 & -0.05 & -0.04 & -0.05 & 0.01 & 0.03 & 0.04 & \\
\hline & $(0.5)$ & $-(1.1)$ & $-(1.2)$ & $-(0.7)$ & $-(0.6)$ & $-(0.7)$ & $(0.1)$ & $(0.4)$ & $(0.5)$ & \\
\hline \multirow[t]{2}{*}{$36-45$} & 0.05 & 0.15 & 0.13 & 0.09 & 0.08 & 0.06 & 0.04 & 0.00 & 0.01 & \\
\hline & $(1.0)$ & $(2.4)$ & $(1.9)$ & $(1.3)$ & $(1.1)$ & $(0.9)$ & $(0.4)$ & $(0.0)$ & $(0.2)$ & \\
\hline \multirow[t]{2}{*}{$46-55$} & -0.02 & -0.02 & -0.01 & 0.02 & 0.01 & -0.03 & -0.15 & 0.01 & 0.00 & \\
\hline & $-(0.3)$ & $-(0.3)$ & $-(0.1)$ & $(0.3)$ & $(0.1)$ & $-(0.4)$ & $-(1.6)$ & $(0.2)$ & $(0.0)$ & \\
\hline \multirow[t]{2}{*}{$56-65$} & -0.19 & -0.22 & -0.03 & -0.04 & -0.01 & -0.05 & 0.02 & -0.16 & -0.16 & \\
\hline & $-(2.2)$ & $-(2.2)$ & $-(0.2)$ & $-(0.4)$ & $-(0.1)$ & $-(0.4)$ & $(0.2)$ & $-(1.2)$ & $-(1.2)$ & \\
\hline
\end{tabular}

Note: $t$-values are based on standard errors allowing for clustering wherever applicable. Estimates use sampling weights wherever applicable.

Sources: Current Population Survey - Merged Outgoing Rotation Group Files (CPS); British Labour Force Survey (BLFS); British Household Panel Survey (BHPS); own calculations. 
Table A9: German Unemployment Regressions (Changes in Transformed Age Coefficients with Respect to 1991 - Corresponding t-values in Parentheses)

\begin{tabular}{|c|c|c|c|c|c|c|c|c|c|}
\hline & 1992 & 1993 & 1994 & 1995 & 1996 & 1997 & 1998 & 1999 & 2000 \\
\hline \multicolumn{10}{|c|}{ Germany (GSOEP) } \\
\hline \multirow[t]{2}{*}{$16-25$} & -0.13 & 0.19 & 0.30 & 0.19 & 0.29 & 0.18 & 0.23 & 0.27 & 0.26 \\
\hline & $-(1.2)$ & $(1.9)$ & $(2.8)$ & $(1.7)$ & $(2.5)$ & (1.4) & $(2.0)$ & $(2.3)$ & $(2.5)$ \\
\hline \multirow[t]{2}{*}{$26-35$} & 0.03 & 0.06 & -0.08 & 0.03 & -0.14 & -0.07 & -0.15 & -0.06 & -0.08 \\
\hline & $(0.4)$ & $(0.8)$ & $-(0.9)$ & $(0.3)$ & $-(1.5)$ & $-(0.8)$ & $-(1.6)$ & $-(0.6)$ & $-(1.0)$ \\
\hline \multirow[t]{2}{*}{$36-45$} & -0.02 & -0.18 & -0.12 & -0.12 & -0.10 & -0.04 & 0.09 & -0.03 & -0.10 \\
\hline & $-(0.2)$ & $-(1.9)$ & $-(1.2)$ & $-(1.2)$ & $-(1.0)$ & $-(0.4)$ & $(0.8)$ & $-(0.3)$ & $-(1.1)$ \\
\hline \multirow[t]{2}{*}{$46-55$} & 0.07 & 0.03 & 0.13 & 0.07 & 0.10 & 0.00 & -0.03 & -0.08 & 0.00 \\
\hline & $(0.7)$ & $(0.2)$ & $(1.1)$ & $(0.6)$ & $(0.9)$ & $(0.0)$ & $-(0.3)$ & $-(0.7)$ & $(0.0)$ \\
\hline \multirow[t]{2}{*}{$56-65$} & 0.01 & -0.09 & -0.25 & -0.25 & -0.06 & 0.00 & -0.13 & -0.02 & 0.03 \\
\hline & $(0.1)$ & $-(0.4)$ & $-(1.2)$ & $-(1.2)$ & $-(0.3)$ & $(0.0)$ & $-(0.7)$ & $-(0.1)$ & $(0.2)$ \\
\hline \multicolumn{10}{|c|}{ Germany (GLFS) } \\
\hline \multirow[t]{2}{*}{$16-25$} & & 0.08 & & 0.06 & 0.11 & 0.12 & & & 0.05 \\
\hline & & $(4.3)$ & & $(3.2)$ & $(6.1)$ & (6.7) & & & $(2.8)$ \\
\hline \multirow[t]{2}{*}{$26-35$} & & -0.01 & & -0.06 & -0.06 & -0.07 & & & -0.10 \\
\hline & & $-(0.7)$ & & $-(4.7)$ & $-(4.8)$ & $-(5.6)$ & & & $-(6.8)$ \\
\hline \multirow[t]{2}{*}{$36-45$} & & -0.01 & & -0.01 & -0.04 & -0.03 & & & -0.03 \\
\hline & & $-(0.6)$ & & $-(0.3)$ & $-(2.5)$ & $-(1.9)$ & & & $-(2.0)$ \\
\hline \multirow[t]{2}{*}{$46-55$} & & -0.07 & & 0.01 & -0.02 & -0.01 & & & 0.06 \\
\hline & & $-(4.7)$ & & $(0.9)$ & $-(1.0)$ & $-(1.0)$ & & & (3.7) \\
\hline \multirow{2}{*}{$56-65$} & & 0.08 & & 0.04 & 0.09 & 0.08 & & & 0.10 \\
\hline & & $(3.5)$ & & $(1.7)$ & $(4.2)$ & (3.6) & & & $(4.5)$ \\
\hline \multicolumn{10}{|c|}{ Germany (IABR) } \\
\hline \multirow[t]{2}{*}{$16-25$} & 0.05 & 0.06 & 0.08 & 0.04 & 0.06 & 0.05 & & & \\
\hline & $(3.7)$ & $(4.4)$ & $(5.5)$ & $(2.4)$ & $(3.6)$ & (2.9) & & & \\
\hline \multirow[t]{2}{*}{$26-35$} & -0.01 & 0.00 & -0.02 & -0.05 & -0.04 & -0.04 & & & \\
\hline & $-(1.2)$ & $(0.4)$ & $-(1.6)$ & $-(4.6)$ & $-(4.0)$ & $-(3.5)$ & & & \\
\hline \multirow[t]{2}{*}{$36-45$} & -0.02 & -0.03 & -0.04 & -0.01 & -0.01 & 0.02 & & & \\
\hline & $-(1.8)$ & $-(2.9)$ & $-(3.2)$ & $-(1.1)$ & $-(0.7)$ & (1.8) & & & \\
\hline \multirow[t]{2}{*}{$46-55$} & 0.00 & -0.02 & 0.01 & 0.04 & 0.03 & 0.03 & & & \\
\hline & $-(0.1)$ & $-(2.1)$ & $(0.4)$ & $(3.3)$ & $(2.4)$ & (2.7) & & & \\
\hline \multirow[t]{2}{*}{$56-65$} & -0.03 & -0.01 & -0.06 & 0.00 & -0.06 & -0.17 & & & \\
\hline & $-(2.4)$ & $-(0.9)$ & $-(3.8)$ & $(0.1)$ & $-(3.7)$ & $-(10.2)$ & & & \\
\hline
\end{tabular}

Note: $t$-values are based on standard errors allowing for clustering wherever applicable. Estimates use sampling weights wherever applicable.

Sources: German Socio-Economic Panel (GSOEP); German Labour Force Survey - Mikrozensus (GLFS); German Adminsitrative Data - Institut für Arbeitsmarkt und Berufsforschung Regionalstichprobe (IABR); own calculations. 
Table A10: U.S. and British Wage Regressions (Changes in Transformed Education Coefficients with Respect to the Base Year - Corresponding t-values in Parentheses)

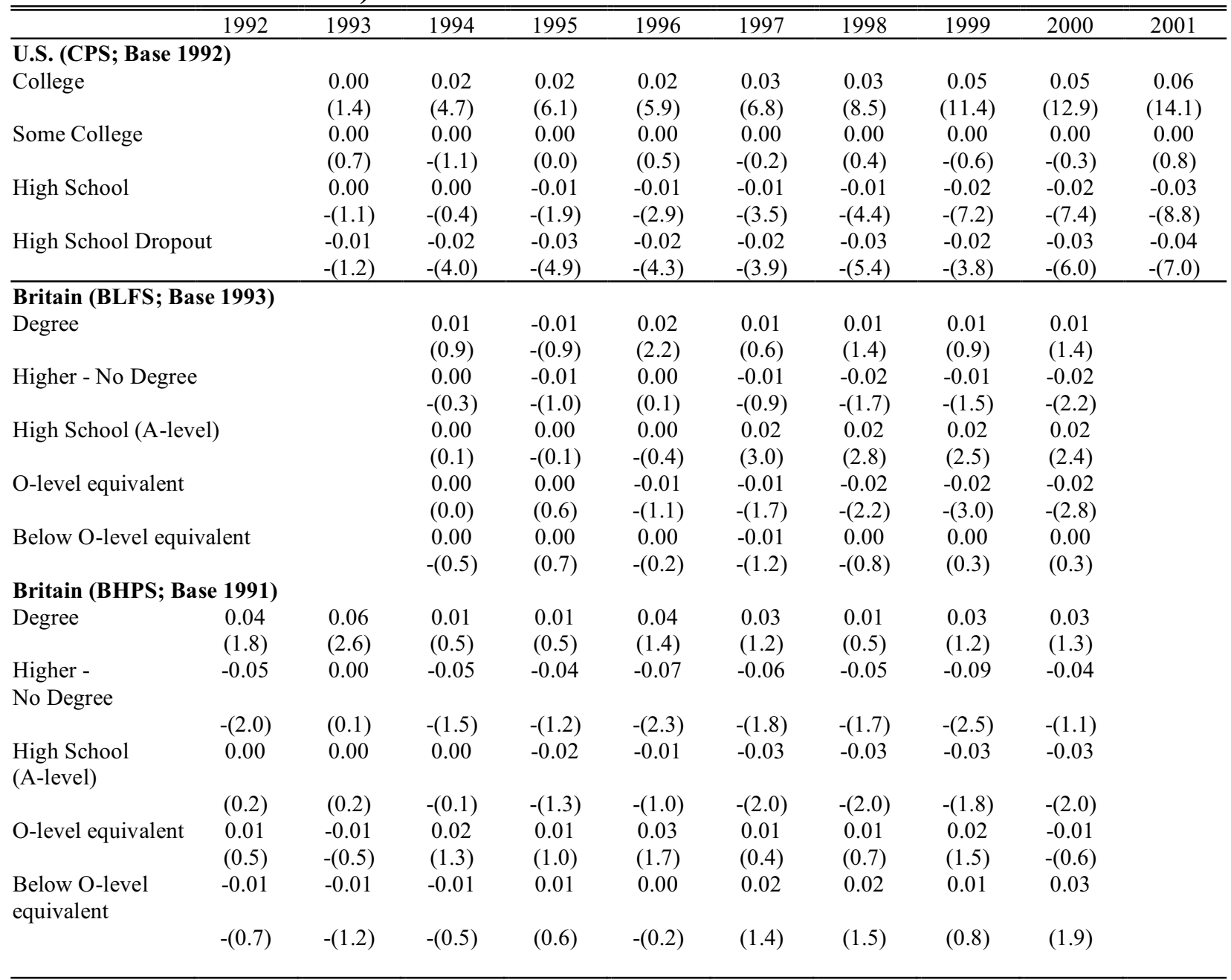

Note: $t$-values are based on standard errors allowing for clustering wherever applicable. Estimates use sampling weights wherever applicable.

Sources: Current Population Survey - Merged Outgoing Rotation Group Files (CPS); British Labour Force Survey (BLFS); British Household Panel Survey (BHPS); own calculations. 
Table A11: German Wage Regressions (Changes in Transformed Education Coefficients with Respect to 1991 - Corresponding t-values in Parentheses)

\begin{tabular}{|c|c|c|c|c|c|c|c|c|c|}
\hline & 1992 & 1993 & 1994 & 1995 & 1996 & 1997 & 1998 & 1999 & 2000 \\
\hline \multicolumn{10}{|l|}{ Germany (GSOEP) } \\
\hline \multirow[t]{2}{*}{ Degree } & 0.00 & 0.01 & -0.02 & -0.06 & -0.05 & -0.10 & -0.12 & -0.06 & -0.07 \\
\hline & $-(0.1)$ & $(0.2)$ & $-(0.7)$ & $-(1.6)$ & $-(1.6)$ & $-(3.4)$ & $-(3.3)$ & $-(1.4)$ & $-(1.5)$ \\
\hline \multirow[t]{2}{*}{ Higher - No Degree } & -0.01 & 0.04 & -0.02 & 0.03 & -0.04 & -0.03 & -0.03 & -0.03 & 0.06 \\
\hline & $-(0.4)$ & $(1.2)$ & $-(0.4)$ & $(0.7)$ & $-(0.9)$ & $-(0.6)$ & $-(0.8)$ & $-(0.6)$ & $(1.6)$ \\
\hline \multirow[t]{2}{*}{ High School - Abitur } & 0.04 & 0.07 & 0.10 & 0.14 & 0.03 & 0.06 & 0.00 & -0.02 & -0.01 \\
\hline & $(0.6)$ & $(1.3)$ & $(1.6)$ & $(2.5)$ & $(0.4)$ & $(0.8)$ & $(0.0)$ & $-(0.2)$ & $-(0.2)$ \\
\hline \multirow[t]{2}{*}{ Apprenticeship } & 0.00 & 0.01 & 0.00 & 0.02 & 0.03 & 0.01 & 0.03 & 0.03 & 0.04 \\
\hline & $-(0.7)$ & $(1.0)$ & $(0.0)$ & $(2.1)$ & $(3.6)$ & $(1.6)$ & $(2.9)$ & $(2.8)$ & $(3.5)$ \\
\hline \multirow[t]{2}{*}{ Below Apprenticeship } & 0.01 & -0.05 & 0.00 & -0.05 & -0.05 & 0.02 & -0.01 & -0.04 & -0.08 \\
\hline & $(0.8)$ & $-(2.4)$ & $(0.2)$ & $-(2.0)$ & $-(2.4)$ & $(0.8)$ & $-(0.3)$ & $-(1.4)$ & $-(2.8)$ \\
\hline \multicolumn{10}{|l|}{ Germany (GLFS) } \\
\hline \multirow[t]{2}{*}{ Higher } & & 0.00 & & -0.03 & -0.05 & -0.06 & & & -0.06 \\
\hline & & $-(0.3)$ & & $-(6.1)$ & $-(11.2)$ & $-(14.5)$ & & & $-(13.6)$ \\
\hline \multirow[t]{2}{*}{ Meister } & & 0.00 & & -0.01 & -0.03 & -0.03 & & & -0.01 \\
\hline & & $-(0.7)$ & & $-(2.3)$ & $-(4.8)$ & $-(5.9)$ & & & $-(1.4)$ \\
\hline \multirow[t]{2}{*}{ High School } & & 0.03 & & 0.04 & 0.06 & 0.06 & & & 0.05 \\
\hline & & $(5.4)$ & & $(6.7)$ & $(9.0)$ & $(9.4)$ & & & $(8.4)$ \\
\hline \multirow{2}{*}{ Apprenticeship } & & 0.00 & & 0.00 & 0.00 & 0.00 & & & 0.00 \\
\hline & & $-(3.2)$ & & $-(1.9)$ & $-(1.1)$ & $-(1.0)$ & & & $-(3.4)$ \\
\hline \multirow[t]{2}{*}{ Below Apprenticeship } & & 0.01 & & 0.02 & 0.03 & 0.04 & & & 0.04 \\
\hline & & (1.4) & & (4.4) & $(7.5)$ & $(9.9)$ & & & $(10.1)$ \\
\hline \multicolumn{10}{|l|}{ Germany (IABR) } \\
\hline \multirow[t]{2}{*}{ Degree } & 0.02 & 0.01 & 0.01 & 0.02 & 0.02 & 0.01 & & & \\
\hline & $(3.8)$ & $(3.7)$ & $(3.5)$ & $(5.6)$ & $(2.6)$ & $(1.5)$ & & & \\
\hline \multirow{2}{*}{$\begin{array}{l}\text { High School and } \\
\text { Apprenticeship }\end{array}$} & 0.02 & 0.02 & 0.02 & 0.02 & 0.03 & 0.03 & & & \\
\hline & $(31)$ & $(42)$ & $(37)$ & $(31)$ & $(42)$ & $(43)$ & & & \\
\hline \multirow{2}{*}{ High School (Abitur) } & 0.02 & 0.02 & 0.02 & 0.04 & 0.07 & -0.01 & & & \\
\hline & $(1.4)$ & (1.1) & $(0.9)$ & $(2.3)$ & $(3.4)$ & $-(0.4)$ & & & \\
\hline \multirow[t]{2}{*}{ Apprenticeship } & 0.00 & 0.00 & 0.01 & 0.01 & 0.01 & 0.01 & & & \\
\hline & $(3.0)$ & $(4.9)$ & $(6.6)$ & (7.3) & $(8.6)$ & $(10.7)$ & & & \\
\hline \multirow[t]{2}{*}{ Below Apprenticeship } & -0.01 & -0.02 & -0.02 & -0.03 & -0.03 & -0.03 & & & \\
\hline & $-(6.8)$ & $-(8.8)$ & $-(10.4)$ & $-(12.4)$ & $-(13.1)$ & $-(13.2)$ & & & \\
\hline
\end{tabular}

Note: $t$-values are based on standard errors allowing for clustering wherever applicable. Estimates use sampling weights wherever applicable.

Sources: German Socio-Economic Panel (GSOEP); German Labour Force Survey - Mikrozensus (GLFS); German Adminsitrative Data - Institut für Arbeitsmarkt und Berufsforschung Regionalstichprobe (IABR); own calculations. 
Table A12: U.S. and British Unemployment Regressions (Changes in Transformed Education Coefficients with Respect to the Base Year - Corresponding tvalues in Parentheses)

\begin{tabular}{|c|c|c|c|c|c|c|c|c|c|c|}
\hline & 1992 & 1993 & 1994 & 1995 & 1996 & 1997 & 1998 & 1999 & 2000 & 2001 \\
\hline \multicolumn{11}{|l|}{$\begin{array}{l}\text { U.S. (CPS; Base 1992) } \\
\end{array}$} \\
\hline \multirow[t]{2}{*}{ College Degree } & & 0.01 & 0.04 & 0.05 & 0.03 & 0.03 & 0.07 & 0.08 & 0.06 & 0.10 \\
\hline & & $(0.9)$ & $(2.6)$ & $(3.2)$ & $(2.0)$ & $(1.7)$ & $(4.1)$ & $(5.1)$ & $(3.5)$ & $(6.2)$ \\
\hline \multirow[t]{2}{*}{ Some College } & & 0.01 & -0.01 & -0.03 & -0.03 & -0.02 & -0.04 & -0.01 & -0.03 & -0.02 \\
\hline & & $(1.1)$ & $-(1.2)$ & $-(2.4)$ & $-(2.0)$ & $-(1.3)$ & $-(2.9)$ & $-(1.0)$ & $-(2.2)$ & $-(1.8)$ \\
\hline \multirow{2}{*}{ High School } & & -0.01 & -0.01 & -0.01 & 0.00 & -0.01 & -0.01 & -0.02 & 0.00 & -0.03 \\
\hline & & $-(1.1)$ & $-(1.2)$ & $-(1.2)$ & $(0.0)$ & $-(0.7)$ & $-(0.6)$ & $-(2.4)$ & $-(0.3)$ & $-(2.8)$ \\
\hline \multirow{2}{*}{\multicolumn{2}{|c|}{ High School Dropout }} & -0.02 & -0.01 & 0.00 & 0.00 & 0.00 & -0.02 & -0.05 & -0.04 & -0.05 \\
\hline & & $-(1.4)$ & $-(0.6)$ & $(0.2)$ & $-(0.2)$ & $(0.1)$ & $-(1.5)$ & $-(3.0)$ & $-(2.1)$ & $-(3.0)$ \\
\hline \multicolumn{11}{|c|}{ Britain (BLFS; Base 1993) } \\
\hline \multirow[t]{2}{*}{ Degree } & & & 0.01 & 0.02 & 0.05 & 0.03 & 0.06 & 0.03 & 0.02 & \\
\hline & & & $(0.5)$ & $(1.0)$ & $(2.2)$ & $(1.6)$ & $(2.7)$ & $(1.5)$ & $(1.1)$ & \\
\hline \multirow[t]{2}{*}{ Higher - No Degree } & & & 0.01 & 0.05 & 0.04 & 0.02 & 0.00 & 0.03 & 0.06 & \\
\hline & & & $(0.4)$ & $(1.7)$ & $(1.3)$ & $(0.7)$ & $(0.0)$ & $(1.1)$ & $(1.9)$ & \\
\hline \multirow[t]{2}{*}{ High School (A-level) } & & & -0.01 & -0.01 & -0.05 & -0.05 & -0.07 & -0.07 & -0.07 & \\
\hline & & & $-(1.2)$ & $-(1.0)$ & $-(3.5)$ & $-(3.8)$ & $-(4.7)$ & $-(4.7)$ & $-(4.7)$ & \\
\hline \multirow[t]{2}{*}{ O-level equivalent } & & & -0.01 & 0.01 & 0.02 & 0.02 & 0.02 & 0.03 & 0.03 & \\
\hline & & & $-(0.6)$ & $(0.4)$ & $(1.6)$ & $(1.1)$ & $(1.2)$ & $(2.1)$ & $(2.1)$ & \\
\hline \multirow{2}{*}{$\begin{array}{l}\text { Below O-level } \\
\text { equivalent }\end{array}$} & & & 0.01 & -0.01 & -0.01 & 0.01 & 0.01 & 0.01 & 0.01 & \\
\hline & & & $(0.9)$ & $-(1.4)$ & $-(0.6)$ & $(0.9)$ & $(1.3)$ & $(0.8)$ & $(0.5)$ & \\
\hline \multicolumn{11}{|c|}{ Britain (BHPS; Base 1991) } \\
\hline \multirow[t]{2}{*}{ Degree } & 0.11 & 0.06 & 0.14 & 0.29 & 0.24 & 0.33 & 0.16 & 0.19 & -0.01 & \\
\hline & $(1.0)$ & $(0.5)$ & $(1.1)$ & $(2.4)$ & $(2.0)$ & $(2.7)$ & $(1.2)$ & $(1.4)$ & $-(0.1)$ & \\
\hline \multirow[t]{2}{*}{ Higher - No Degree } & -0.07 & 0.11 & 0.07 & 0.11 & -0.33 & 0.13 & 0.37 & -0.03 & 0.21 & \\
\hline & $-(0.4)$ & $(0.7)$ & $(0.4)$ & $(0.6)$ & $-(1.7)$ & $(0.7)$ & $(2.0)$ & $-(0.1)$ & $(1.2)$ & \\
\hline \multirow[t]{2}{*}{ High School (A-level) } & -0.05 & -0.10 & 0.03 & -0.09 & 0.00 & -0.01 & -0.04 & -0.04 & -0.02 & \\
\hline & $-(0.8)$ & $-(1.6)$ & $(0.5)$ & $-(1.3)$ & $(0.0)$ & $-(0.1)$ & $-(0.6)$ & $-(0.6)$ & $-(0.3)$ & \\
\hline \multirow[t]{2}{*}{ O-level equivalent } & -0.04 & -0.02 & -0.10 & 0.05 & 0.03 & -0.05 & -0.07 & -0.01 & -0.08 & \\
\hline & $-(0.7)$ & $-(0.4)$ & $-(1.6)$ & $(0.8)$ & $(0.4)$ & $-(0.8)$ & $-(0.9)$ & $-(0.1)$ & $-(1.0)$ & \\
\hline \multirow{2}{*}{$\begin{array}{l}\text { Below O-level } \\
\text { equivalent }\end{array}$} & 0.04 & 0.05 & 0.00 & -0.07 & -0.02 & -0.07 & -0.04 & -0.01 & 0.03 & \\
\hline & (1.1) & $(1.1)$ & $-(0.1)$ & $-(1.4)$ & $-(0.4)$ & $-(1.4)$ & $-(0.6)$ & $-(0.2)$ & $(0.5)$ & \\
\hline
\end{tabular}

Note: $t$-values are based on standard errors allowing for clustering wherever applicable. Estimates use sampling weights wherever applicable.

Sources: Current Population Survey - Merged Outgoing Rotation Group Files (CPS); British Labour Force Survey (BLFS); British Household Panel Survey (BHPS); own calculations. 
Table A13: German Unemployment Regressions (Changes in Transformed Education Coefficients with Respect to 1991 - Corresponding t-values in Parentheses)

\begin{tabular}{|c|c|c|c|c|c|c|c|c|c|}
\hline & 1992 & 1993 & 1994 & 1995 & 1996 & 1997 & 1998 & 1999 & 2000 \\
\hline \multicolumn{10}{|l|}{$\overline{\text { Germany (GSOEP) }}$} \\
\hline \multirow[t]{2}{*}{ Degree } & -0.24 & -0.24 & -0.07 & -0.08 & 0.10 & -0.34 & -0.08 & -0.29 & -0.09 \\
\hline & $-(1.2)$ & $-(1.4)$ & $-(0.4)$ & $-(0.5)$ & $(0.6)$ & $-(2.0)$ & $-(0.5)$ & $-(1.6)$ & $-(0.6)$ \\
\hline \multirow[t]{2}{*}{ Higher - No Degree } & -0.52 & -0.70 & -0.39 & -0.47 & -0.19 & -0.04 & -0.46 & -0.52 & -0.16 \\
\hline & $-(2.3)$ & $-(3.4)$ & $-(1.9)$ & $-(2.3)$ & $-(0.8)$ & $-(0.2)$ & $-(2.2)$ & $-(2.5)$ & $-(0.9)$ \\
\hline \multirow[t]{2}{*}{ High School - Abitur } & 0.17 & 0.11 & -0.22 & 0.18 & 0.08 & -0.05 & 0.08 & 0.10 & 0.09 \\
\hline & $(0.9)$ & $(0.5)$ & $-(0.8)$ & $(0.7)$ & $(0.3)$ & $-(0.2)$ & $(0.3)$ & $(0.4)$ & $(0.4)$ \\
\hline \multirow[t]{2}{*}{ Apprenticeship } & 0.11 & 0.14 & 0.12 & 0.07 & 0.02 & 0.10 & 0.07 & 0.07 & -0.01 \\
\hline & $(2.4)$ & $(3.1)$ & $(2.7)$ & $(1.6)$ & $(0.4)$ & $(2.0)$ & $(1.4)$ & $(1.5)$ & $-(0.1)$ \\
\hline \multirow[t]{2}{*}{ Below Apprenticeship } & -0.03 & -0.04 & -0.14 & -0.03 & -0.05 & -0.06 & -0.02 & 0.10 & 0.09 \\
\hline & $-(0.3)$ & $-(0.5)$ & $-(1.5)$ & $-(0.3)$ & $-(0.5)$ & $-(0.6)$ & $-(0.2)$ & $(1.0)$ & $(1.1)$ \\
\hline \multicolumn{10}{|l|}{ Germany (GLFS) } \\
\hline \multirow[t]{2}{*}{ Higher } & & -0.06 & & -0.07 & -0.12 & -0.16 & & & -0.15 \\
\hline & & $-(2.6)$ & & $-(2.7)$ & $-(5.2)$ & $-(6.8)$ & & & $-(5.9)$ \\
\hline \multirow[t]{2}{*}{ Meister } & & -0.06 & & -0.02 & -0.06 & -0.09 & & & -0.15 \\
\hline & & $-(1.8)$ & & $-(0.8)$ & $-(2.1)$ & $-(2.8)$ & & & $-(4.6)$ \\
\hline \multirow[t]{2}{*}{ High School } & & -0.07 & & -0.08 & -0.16 & -0.13 & & & -0.16 \\
\hline & & $-(2.2)$ & & $-(2.4)$ & $-(5.0)$ & $-(4.2)$ & & & $-(5.2)$ \\
\hline \multirow[t]{2}{*}{ Apprenticeship } & & 0.03 & & 0.02 & 0.04 & 0.05 & & & 0.05 \\
\hline & & $(3.4)$ & & $(2.2)$ & $(5.6)$ & $(6.7)$ & & & $(6.8)$ \\
\hline \multirow[t]{2}{*}{ Below Apprenticeship } & & 0.02 & & 0.03 & 0.04 & 0.04 & & & 0.06 \\
\hline & & $(1.0)$ & & $(1.9)$ & $(2.5)$ & $(2.8)$ & & & $(4.0)$ \\
\hline \multicolumn{10}{|l|}{ Germany (IABR) } \\
\hline \multirow[t]{2}{*}{ Degree } & -0.04 & -0.13 & -0.12 & -0.11 & -0.08 & -0.11 & & & \\
\hline & $-(1.4)$ & $-(4.9)$ & $-(4.6)$ & $-(4.1)$ & $-(3.1)$ & $-(4.1)$ & & & \\
\hline \multirow{2}{*}{$\begin{array}{l}\text { High School and } \\
\text { Apprenticeship }\end{array}$} & -0.09 & -0.13 & -0.13 & -0.18 & -0.17 & -0.18 & & & \\
\hline & $-(2.2)$ & $-(3.1)$ & $-(3.2)$ & $-(4.2)$ & $-(4.1)$ & $-(4.3)$ & & & \\
\hline \multirow[t]{2}{*}{ High School (Abitur) } & -0.01 & 0.00 & -0.02 & -0.09 & -0.07 & -0.08 & & & \\
\hline & $-(0.2)$ & $(0.0)$ & $-(0.3)$ & $-(1.5)$ & $-(1.1)$ & $-(1.4)$ & & & \\
\hline \multirow[t]{2}{*}{ Apprenticeship } & 0.00 & 0.00 & -0.01 & -0.01 & -0.01 & -0.01 & & & \\
\hline & $(0.5)$ & $(0.7)$ & $-(1.7)$ & $-(1.3)$ & $-(2.4)$ & $-(2.5)$ & & & \\
\hline \multirow[t]{2}{*}{ Below Apprenticeship } & 0.01 & 0.04 & 0.06 & 0.06 & 0.07 & 0.08 & & & \\
\hline & $(1.4)$ & $(3.9)$ & $(6.4)$ & $(6.5)$ & $(6.8)$ & $(7.8)$ & & & \\
\hline
\end{tabular}

Note: $t$-values are based on standard errors allowing for clustering wherever applicable. Estimates use sampling weights wherever applicable.

Sources: German Socio-Economic Panel (GSOEP); German Labour Force Survey - Mikrozensus (GLFS); German Adminsitrative Data - Institut für Arbeitsmarkt und Berufsforschung Regionalstichprobe (IABR); own calculations. 


\section{DAVIDSON INSTITUTE WORKING PAPER SERIES - Most Recent Papers}

The entire Working Paper Series may be downloaded free of charge at: www.wdi.bus.umich.edu

CURRENT AS OF 3/31/05

\begin{tabular}{|c|c|c|}
\hline Publication & Authors & Date \\
\hline $\begin{array}{l}\text { No. 762: Transatlantic Differences in Labour Markets Changes in Wage } \\
\text { and Non-Employment Structures in the 1980s and the 1990s }\end{array}$ & Patrick A. Puhani & Mar. 2005 \\
\hline $\begin{array}{l}\text { No. 761: Resolution, Recovery and Survival: The Evolution of Payment } \\
\text { Disputes in Post-Socialist Europe }\end{array}$ & William Pyle & Mar. 2005 \\
\hline $\begin{array}{l}\text { No. 760: Official Foreign Exchange Interventions in the Czech } \\
\text { Republic: Did They Matter? }\end{array}$ & Balázs Égert and Luboš Komárek & Mar. 2005 \\
\hline $\begin{array}{l}\text { No. 759: Assessing Market Expectations on Exchange Rates and } \\
\text { Inflation: A Pilot Forecasting System for Bulgaria }\end{array}$ & \begin{tabular}{|l} 
Michael Berlemann, Kalina \\
Dimitrova, \& Nikolay Nenovsky
\end{tabular} & Mar. 2005 \\
\hline No. 758: Attitudes and Performance: An Analysis of Russian Workers & $\begin{array}{l}\text { Susan J. Linz and Anastasia } \\
\text { Semykina } \\
\end{array}$ & Mar. 2005 \\
\hline $\begin{array}{l}\text { No. 757: Barter, Credit, and Welfare: A theoretical inquiry into the } \\
\text { barter phenomenon in Russia }\end{array}$ & José Noguera and Susan J. Linz & Mar. 2005 \\
\hline $\begin{array}{l}\text { No. 756: Sorting, Selection, and Transformation of the Return to } \\
\text { College Education In China }\end{array}$ & $\begin{array}{l}\text { Belton M. Fleisher, Haizheng Li, } \\
\text { Shi Li, and Xiaojun Wang }\end{array}$ & Mar. 2005 \\
\hline $\begin{array}{l}\text { No. 755: Foreign Exchange Interventions in Emerging Europe: } \\
\text { Should We Give a Damn? The Case of Croatia and Turkey }\end{array}$ & Balázs Égert & Mar. 2005 \\
\hline $\begin{array}{l}\text { No. 754: Targeting Relative Inflation Forecast as Monetary Policy } \\
\text { Framework for Adopting Euro }\end{array}$ & T. Orlowski & Feb. 2005 \\
\hline $\begin{array}{l}\text { No. 753: Internet Entrepreneurship: Networks and Performance of } \\
\text { Internet Ventures In China }\end{array}$ & gal & Feb. 2005 \\
\hline $\begin{array}{l}\text { No. 752: Network Triads: Transitivity, Referral and Venture Capital } \\
\text { Decisions in China and Russia }\end{array}$ & argal & Feb. 2005 \\
\hline $\begin{array}{l}\text { No. 751: Software Entrepreneurship: Knowledge Networks and } \\
\text { Performance Of Software Ventures In China and Russia }\end{array}$ & $\overline{\text { argal }}$ & Feb. 2005 \\
\hline $\begin{array}{l}\text { No. 750: Retained State Shareholding in Chinese PLCs: Does } \\
\text { Government Ownership Reduce Corporate Value? }\end{array}$ & Lihui Tian and Saul Estrin & Feb. 2005 \\
\hline No. 749: Financial Development and Technology & Solomon Tadesse & Feb. 2005 \\
\hline No. 748: Banking Fragility and Disclosure: International Evidence & Solomon Tadesse & Feb. 2005 \\
\hline $\begin{array}{l}\text { No. 747: Consolidation, Scale Economies and Technological Change in } \\
\text { Japanese Banking }\end{array}$ & Solomon Tadesse & Feb. 2005 \\
\hline $\begin{array}{l}\text { No. 746: Trade Creation and Diversion Effects of Europe’s Regional } \\
\text { Liberalization Agreements }\end{array}$ & Yener Kandogan & Feb. 2005 \\
\hline No. 745: Quality of Institutions, Credit Markets and Bankruptcy & Christa Hainz & Feb. 2005 \\
\hline $\begin{array}{l}\text { No. 744: How Transition Paths Differ: Enterprise Performance in Russia } \\
\text { and China }\end{array}$ & Sumon Bhaumik and Saul Estrin & Jan. 2005 \\
\hline $\begin{array}{l}\text { No. 743: Inflation Targeting, Between Rhetoric and Reality. The Case } \\
\text { of Transition Economies }\end{array}$ & Daniel Daianu and Laurian Lungu & Jan. 2005 \\
\hline $\begin{array}{l}\text { No. 742: How Does Law Affect Finance? An Empirical Examination of } \\
\text { Tunneling in an Emerging Market }\end{array}$ & \begin{tabular}{|l} 
Vladimir Atanasov, Con \\
Ciccotello, \& Stanley B \\
\end{tabular} & Jan. 2005 \\
\hline $\begin{array}{l}\text { No. 741: Do Insider Trading Laws Matter? Some Preliminary } \\
\text { Comparative Evidence }\end{array}$ & Laura Nyantung Beny & Jan. 2005 \\
\hline $\begin{array}{l}\text { No. 740: Autopsy on an Empire: Understanding Mortality in Russia and } \\
\text { the Former Soviet Union }\end{array}$ & $\begin{array}{l}\text { Elizabeth Brainerd and David M. } \\
\text { Cutler }\end{array}$ & Jan. 2005 \\
\hline $\begin{array}{l}\text { No. 739: Not Separate, Not Equal: Poverty and Inequality in Post- } \\
\text { Apartheid South Africa }\end{array}$ & $\begin{array}{l}\text { Johannes G. Hoogeveen and Berk } \\
\text { Özler } \\
\end{array}$ & Jan. 2005 \\
\hline $\begin{array}{l}\text { No. 738: The Marketing Structure in Agribusiness during the Transition } \\
\text { in Bulgaria }\end{array}$ & $\begin{array}{l}\text { Steve Murray, Yordan Staykov, } \\
\text { and Valentin Katzerov } \\
\end{array}$ & Jan. 2005 \\
\hline No. 737: Passive Creditors & $\begin{array}{l}\text { Koen Schoors and Konstantin } \\
\text { Sonin }\end{array}$ & Jan. 2005 \\
\hline $\begin{array}{l}\text { No. 736: From a currency board to the euro: Public attitudes toward } \\
\text { unilateral euroization in Bulgaria }\end{array}$ & Neven T. Valev & Jan. 2005 \\
\hline No. 735: Dictators and Their Viziers: Agency Problems in Dict & $\begin{array}{l}\text { Georgy Egorov and Konstantin } \\
\text { Sonin }\end{array}$ & Jan. 2005 \\
\hline
\end{tabular}

